\title{
Mineralogy of the ceramic slags from the Bronze Age funerary site at Lăpuş (NW Romania)
}

\author{
Volker HOECK, Corina IONESCU, Carola METZNER-NEBELSICK \\ and Louis D. NEBELSICK
}

Hoeck V., Ionescu C., Metzner-Nebelsick C. and Nebelsick L.D. (2012) - Mineralogy of the ceramic slags from the Bronze Age funerary site at Lăpuş (NW Romania). Geol. Quart., 56 (4): 649-664, doi: 10.7306/gq.1047

\begin{abstract}
A Bronze Age (13-12th century B.C.) necropolis and cult area in Lăpuş (NW Romania) has been studied. The mound investigated during the present campaign covered a multi-phased wooden cult building containing bronze objects, ceramic potshards and slag pieces. The latter have a mammillary smooth surface, irregular shape and a high porosity. Optical microscopy reveals a colourless to brown vitreous mass, full with various-sized pores making up to $40 \mathrm{vol} \%$ of the total slag. The glass includes relic phases, e.g., quartz, partly melted plagioclase and rutile, rare zircon, ilmenite and magnetite-rich spinel. Cristobalite and various silicates and oxides were formed within the glass and at the wall of the vesicles during cooling. The latter include fayalite, ferrosilite, magnetite-dominated spinel, hematite, clinopyroxene, mullite and cordierite. About $1 / 3$ of the total volume of the slag consists of glass with a wide variety of $\mathrm{SiO}_{2}$ ranging from 49 to 76 wt.\%. It is inhomogeneous, with local enrichment in $\mathrm{Fe}, \mathrm{Ca}, \mathrm{Mg}$, Ti and $\mathrm{K}$. The pore structure, the partial melting of plagioclase and rutile, the newly formed $\mathrm{SiO}_{2}$ polymorphs (cristobalite) and the $\mathrm{Fe}(\mathrm{Al})$ silicates indicate maximum temperatures of $1100-1200^{\circ} \mathrm{C}$ for the fire generating the slags. The slags are not related to any metallurgical but to an anthropogenic pyrometamorphic process and formed as a result of overfiring some ceramic vessels which may have contained ritual offerings. Intentionally initiated firing of the wooden structures is the most likely the agent of this high temperature. The slags resemble buchites and can be termed "ceramic slags".
\end{abstract}

Volker Hoeck and Corina Ionescu, Department Geography and Geology, Paris Lodron University, Hellbrunner 34, A-5020 Salzburg, Austria; Department Geology, Babeș-Bolyai University, Kogălniceanu 1, 400084 Cluj-Napoca, Romania, e-mails. volker.hoeck@sbg.ac.at, corina.ionescu@ubbcluj.ro; Carola Metzner-Nebelsick, Institut für Vor- und Frühgeschichtliche Archäologie und Provinzialrömische Archäologie, Ludwig Maximilian University, Geschwister-Scholl-Platz 1, 80539 München, Germany, e-mail: Metzner-Nebelsick@vfpa.fak12.uni-muenchen.de; Louis D. Nebelsick, Cardinal Stefan Wyszyński University, Institute of Archaelogy, Dewajtis 5, 01-815 Warszawa, Poland; Landesamt für Archäologie Halle, Germany, e-mail: LuC.Nebelsick@t-on line.de (received: June 1, 2012; accepted: August 1, 2012; first published online: October 18, 2012).

Key words: Romania, Bronze Age, electron microprobe analysis, ceramic slag, glass.

\section{INTRODUCTION}

Finds collected during excavations of archaeological sites include a large variety of artifacts, some of them more common than others. Usually, the archaeometrist focuses on ceramics, metallic objects, gemstones, lithics, less attention is given on textiles, bones, wood (when preserved), slags etc. This is unfortunate as the slags particularly are very important, being commonly associated with metal smelting. The term slag describes a mostly artificial, highly vesicular vitreous material, which includes various mineral relics and is mainly used in six connotations:

1. "A byproduct of the firing of ores, metals, flux and fuel that contains non-economic constituents of the furnace charge"
(Neuendorf et al., 2005). In this sense slags are usually associated with smelting of gold, silver, copper, lead, iron or bronze (e.g., Serneels and Crew, 1997; Buchwald and Wivel, 1998; Degryse et al., 2003; Hein et al., 2007; Blakelock et al., 2009; Heimann et al., 2010; Sharp and Mittwede, 2011; Rehren et al., 2012 and referencees therein). The melted silicates, sulphides, carbonates and/or oxides which constitute the gangue of the ore will separate from the melted metal as "foam". Due to the fast cooling, the latter will solidify into a glassy, highly porous material, which is the slag.

2. A scoriaceous or cindery pyroclastic rock (volcanic scoria) i.e. a quenched vesicular silicic material (see Sigurdsson et al., 2000). Therefore, slags are sometimes also termed "scoria" (e.g., Serneels, 1995; Anderson et al., 2003). 
3. The pyrolysis/melting treatment of solid waste can also produce slags (Traber et al., 2002; Saffarzadeh et al., 2006).

4. Slag-like materials may result from overfiring/burning soil or sediments (Thy et al., 1995; Grapes, 2006, 2011; Grapes et al., 2009, 2011), earthen bricks i.e. adobe, or the ash that results from firing dung or vegetable remains (Magee et al., 1996; Canti, 2003).

5. Many archaeological studies mention slag pieces found together with ceramic shards (e.g., Alden, 1988; Golden, 2009; Issi et al., 2011; Petrie, 2012). A careless or uncontrolled firing can lead to partly slaggy pottery.

6. Slag may form by melting the clay-based kiln walls (Shoval, 1993; Stone and Zimansky, 2004; Zacharias et al., 2006; Blakelock et al., 2009) or the clay tuyères used in the smelting or casting process (Veldhuijzen, 2005).

In particular the last three connotations can be included into pyrometamorphism, which is used for a very high temperature and low pressure metamorphism, also involving fusion.

In the Bronze Age Lăpuş necropolis and cult area (Fig. 1) ceramic shards, slags, bronze objects as well as the oldest iron axe in Europe were exhumed (Metzner-Nebelsick et al., 2010). As no traces of metal smelting have been found to date, several questions related to these slags arose: Do they bear metal traces? Are they the byproducts of $\mathrm{Cu}$, Au or even Fe smelting or the remnants of sacrificial processes that include pottery burning? Have the slag pieces been formed during one or several separate melting/quenching events? Our aim was to inves- tigate this material combining mineralogical/petrographic and microchemical analysis, i.e. optical microscopy in polarized light (OM), X-ray powder diffraction (XRPD) and electron microprobe analysis (EMPA) following Neuffer (1997) who noticed the difficulty to make a clear distinction among various slag types without detailed analytical investigation of their composition and fabric.

\section{ARCHAEOLOGICAL AND GEOLOGICAL BACKGROUND}

The Lăpuş archaeological site, located on the eastern terrace of the Lăpuş River (47²8'12”'N and 2359'15” E; Fig. 1), is the largest surviving Late Bronze Age barrow necropolis in the Eastern Carpathian region discovered to date (MetznerNebelsick et al., 2010). The ${ }^{14} \mathrm{C}$ dating of more than twenty samples of charred burned wood and cereals from the site dates it precisely to the 13-12th century B.C. (Metzner-Nebelsick et al., 2010).

According to Kacsó (1975), the site was discovered in 1890 by János Szendrei, who investigated 13 barrows, but unfortunately no documentation or finds survived. Research was interrupted for almost 80 years until the 1960's when worked resumed at the site. It was discovered to be a vast spread of barrows clustering into various groups and covering about $1.5 \mathrm{~km}^{2}$. Subsequent systematic research led to the investiga-

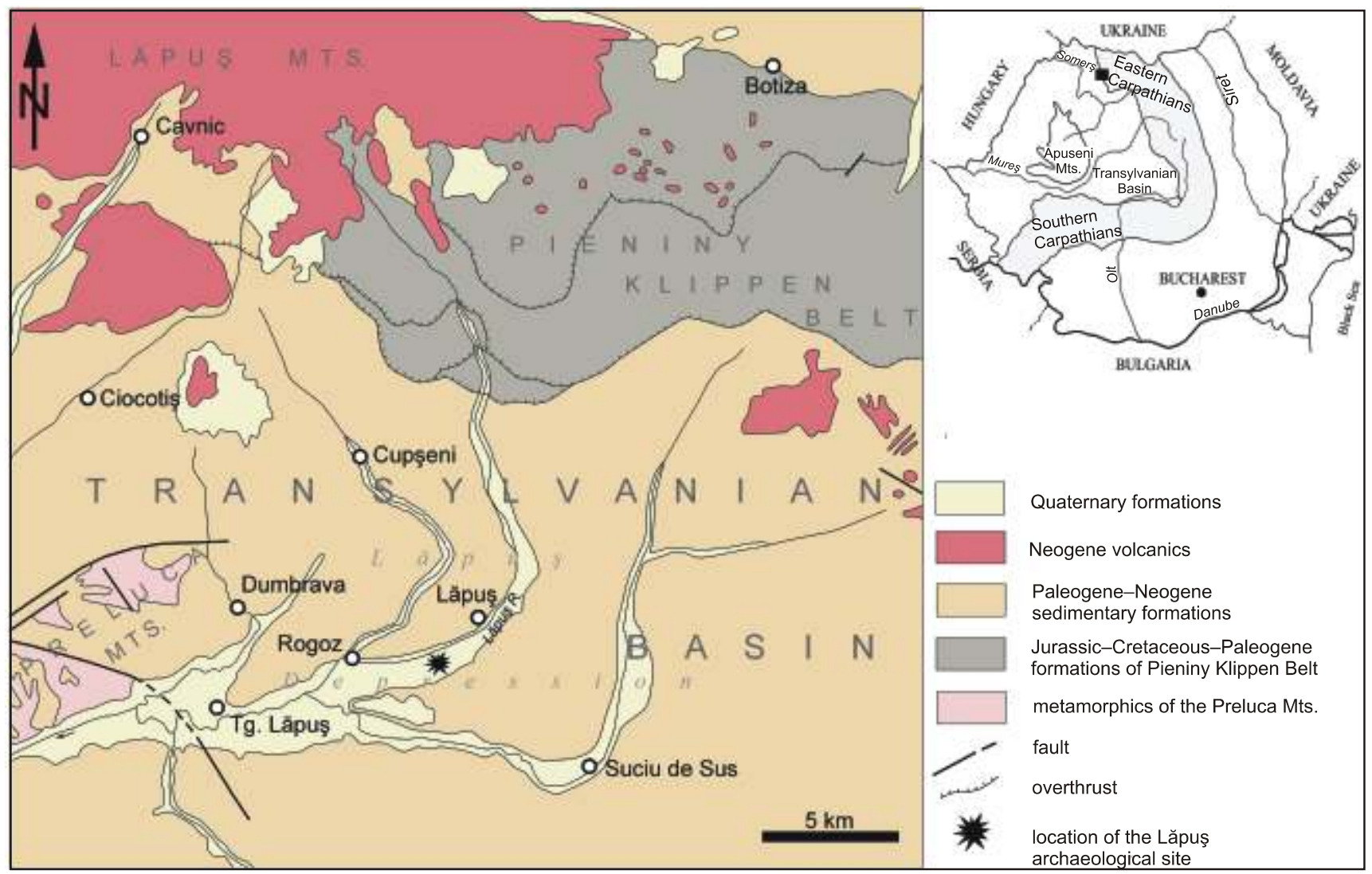

Fig. 1. Simplified geological map of the Lăpuş Depression and surroundings (based on Giuşcă et al., 1967; Ianovici et al., 1968; Săndulescu, 1984)

The insert in upper right shows the position of the area within the Romanian territory 
tion of twenty-seven tumuli until 2006 (for details see Kacsó, 1975; Kacsó et al., 2012). Barrow no. 26 which is currently under investigation is a complex multi-phased structure. Initially a clay/soil platform was raised on which a building was erected and later set on fire. Afterwards, the building remains were covered by a substantial clay/soil layer creating a new platform on which a further monumental building was erected and once again burnt and covered with a clay layer thus creating an oval shaped barrow. These multi-phased building complex probably functioned as a gathering place for feasting and sacrifice, in the context of funeral rituals and/or ancestor worship.

The structures buried in the mound display wooden wall foundations and postholes of the wooden buildings, stone pavements and constructions including a cobbled way leading to the barrow, large pottery packings and systematically distributed pit complexes. Like previously excavated burial mounds, barrow no. 26 contains large amounts of most likely intentionally broken pottery (Kacsó, 1975; Metzner-Nebelsick et al., 2010), burnt daub from construction walls, stone casting moulds and other small finds which had been deposited outside the building, as well as cremated animal bones and charred plant remains. Scattered $\mathrm{mm}$ - to $\mathrm{cm}$-sized dark gray slag pieces (Fig. 2A) were collected all over the site. The pottery assemblage found in this barrow is typical for ceramic inventories of the Lăpuş tumuli and includes large conical necked vessels, richly decorated fine ware cups and bowls, as well as coarse ware such as large pots. Many potsherds (Fig. 2B) display signs of (over)burning/refiring, such as cracked black surface, partial melting and deformation (Kacsó, 1975; Metzner-Nebelsick et al., 2010). It is assumed that the thousands of pottery sherds discovered in this and other barrows are rather the remains of ritual feasting than classical grave goods (Metzner-Nebelsick et al., 2010). No remnants of any type of kilns for either ceramic or smelting have been identified on the site so far. Metal finds from previously excavated barrows (Kacsó, 2001) include bronze axes and daggers, as well as bronze and golden jewellery. The iron axe exhumed in one of the barrows is one of the earliest iron artefacts in Europe (Kacsó, 1975; MetznerNebelsick et al., 2010).

Geologically, the area of the archaeological site belongs to the northern part of the Transylvanian Basin (Romania). Here, at the foothills of the Eastern Carpathians, Neogene clays, marly clays, marls, sandstones, sands and limestones crop out. To the west, micaschists, gneisses, crystalline limestones and amphibolites of the Preluca Mts. (Apuseni Mts.) occur (Giuşcă et al., 1967; Ianovici et al., 1968; Săndulescu et al., 1978). The Lăpuş Mts. belong to the Eastern Carpathians and form the northern rim of the Lăpuş Depression. They are built up of SarmatianPannonian andesites and basaltic andesites with associated $\mathrm{Cu}-\mathrm{Pb}-\mathrm{Zn} \pm \mathrm{Au}-\mathrm{Ag}$ mineralisations. East of the Lăpuş Mts., the Upper Jurassic-Cretaceous-Paleogene sediments of the Pieniny Klippen Belt such as limestones, sandstones, marls and clays crop out. West of the site, the Lăpuş River carries sediments collected in the spring catchments covering Neogene volcanics of the Eastern Carpathians, Neogene sediments of the Transylvanian Basin as well as the sedimentary formations of the Pieniny Klippen Belt. The river plains are covered with Quaternary alluvial sediments, i.e. sands, silts, mudstones and gravels.

\section{SAMPLES AND METHODS}

From numerous slag pieces found scattered at A4 Complex 305 Podanc (tumulus 26), four samples labeled LP1, LP3b, LP8a (Fig. 2A) and LP15, which were large enough to allow various analyses, were chosen for the study. Each piece was carefully and thoroughly washed, to remove all soil particles which could enter into the pores. Finally, the whole material was cleaned with water in an ultrasonic bath (Bandelin-Sonorex Rk 100 equipment; University of Salzburg). After cutting several slices for OM and EMPA thin sections, a piece of slag of
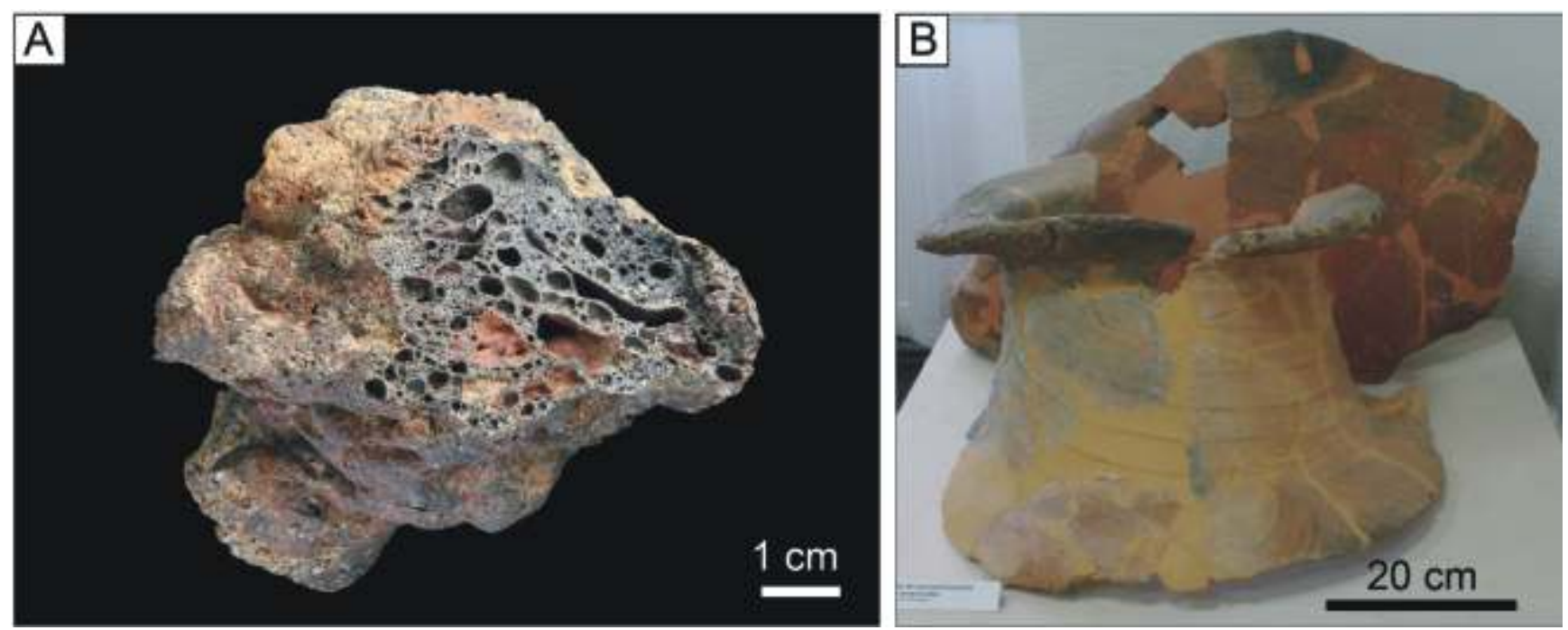

Fig. 2. Slag (A) and deformed pots (B) found in Lăpuş

Fresh cut of the interior of the slag piece (sample LP8a) displaying variously-sized and -shaped pores; the surface of some of the pores is lined with a reddish pellicle; slag photos by Dr. F. Forray; reconstructed pot photos by O. Thiel; the pots were found in the barrow no. 20 (Kacsó, 2001) and are presently displayed at the Maramureş County Museum for History and Archaeology 
cca 25-30 g destined to XRPD was crushed in smaller pieces and cleaned again to eliminate any possible soil contamination.

Four polished thin sections (samples LP1, LP3b, LP8a and LP15) were coated with carbon and analysed at Salzburg University with a JXA Superprobe 8600 equipped with four wavelength dispersive spectrometers (WDS) and one $\mathrm{Si}(\mathrm{Li})$ energy-dispersive spectrometer (EDS). The electron microprobe operated at $15 \mathrm{kV}$ accelerating voltage, $40 \mathrm{nA}$ beam current and $\leq 5 \mu \mathrm{m}$ electron-beam diameter. The standards were: quartz for $\mathrm{Si}$, synthetic $\gamma-\mathrm{Al}_{2} \mathrm{O}_{3}$ for $\mathrm{Al}$, synthetic $\mathrm{FeO}$ for $\mathrm{Fe}$, rutile for $\mathrm{Ti}$, apatite for $\mathrm{Ca}$ and $\mathrm{P}$, synthetic $\mathrm{MgO}$ for $\mathrm{Mg}, \mathrm{NaCl}$ for $\mathrm{Na}$, $\mathrm{KCl}$ for $\mathrm{K}, \mathrm{MnO}$ for $\mathrm{Mn}, \mathrm{Cr}_{2} \mathrm{O}_{3}$ for $\mathrm{Cr}$, metallic nickel for $\mathrm{Ni}$, and $\mathrm{Ba}-\mathrm{Na}-\mathrm{K}$ synthetic glass for $\mathrm{Ba}$, respectively. The final compositions were calculated following the ZAF procedure. The detection limits $(2 \delta)$ were 0.02 wt. $\%$ for $\mathrm{MgO}, \mathrm{CaO}, \mathrm{Na}_{2} \mathrm{O}$ and $\mathrm{K}_{2} \mathrm{O}, 0.03$ wt. $\%$ for $\mathrm{Al}_{2} \mathrm{O}_{3}$ and $\mathrm{MnO}, 0.04$ wt.\% for $\mathrm{TiO}_{2}$, 0.05 wt. \% for $\mathrm{SiO}_{2}, 0.06 \mathrm{wt} . \%$ for $\mathrm{FeO}$ and $\mathrm{NiO}, 0.07 \mathrm{wt} . \%$ for $\mathrm{P}_{2} \mathrm{O}_{5}, \mathrm{Cr}_{2} \mathrm{O}_{3}$ and $\mathrm{BaO}$ (see also Ionescu and Hoeck, 2011). The counting time was $20 \mathrm{~s}$ for the peak and $10 \mathrm{~s}$ for the background. The analytical error is between 0.5 and $1 \%$ at high concentrations, between 5 and $10 \%$ at low concentrations and about $30 \%$ close to the detection limit. The measured values lower than the detection limits were marked in tables as "below detection limit". As most of the $\mathrm{Cr}_{2} \mathrm{O}_{3}$ and $\mathrm{NiO}$ data are below the detection limits, they are not included in the tables.

A total of 151 micropoint analyses were obtained: 74 on glass, 10 on feldspars, 8 on $\mathrm{SiO}_{2}$ phases, 11 on Ti compounds and 48 on various other phases. The EMPA study focused on the identification of primary and secondary mineral phases and clarifying their mutual relationship achieved during meltingcooling process.

For the phase identification, X-ray powder diffraction was carried with an automatic Siemens D500 Bragg-Brentano diffractometer (University of Salzburg) equipped with a secondary graphite monochromator. About 25-30 g of slag were milled in an agate mortar and homogenized. From it, few grams were measured from 3 to $75^{\circ} 2 \theta\left(3 \mathrm{~s} / 0.02^{\circ} 2 \theta\right)$ with CuKa radiation, at $40 \mathrm{kV}$ voltage and $45 \mathrm{~mA}$ current.

\section{RESULTS: MINERALOGY OF SLAGS}

The slag pieces show a dark grey colour, sometimes strapped with whitish bands, and a smooth, lustrous mammillary surface (Fig. 2A). The shape is rough, more or less irregular, ranging from isometric to elongate. The size is from $<1 \mathrm{~cm}$ up to $10-15 \mathrm{~cm}$ in diameter. The slag body is light due to the high porosity, expressed by variously sized voids/vesicles, ranging from small (few micrometers) to very large (1-3 cm across). Most of the voids have a perfectly rounded, i.e. spherical shape but elongated or highly irregular pores are not uncommon. Some of the pores are lined with a bright red material (Fig. 2A).

\section{OPTICAL MICROSCOPY}

The polarized light microscopy shows, in all four samples, a highly porous vitreous mass (Fig. 3A) with an inhomo- geneous appearance i.e. a mix of colourless and brown parts (Fig. 3B, C). It includes mostly quartz. Plagioclase, ilmenite, Fe-oxides, rutile, spinel and zircon were identified as well. Together with quartz, which shows sometimes wavy extinction, there are numerous small grains of $\alpha$-cristobalite displaying low refractive index and a very low birefringence (Fig. 3D). In the glass, colourless needle-like crystals of mullite were also observed (Fig. 3E). Clasts consisting of polycrystalline quartz reach up to $\sim 0.5$ to $\sim 1.5 \mathrm{~mm}$ in diameter. An inclusion of siltstone shows a glassy rim (Fig. 3F).

\section{X-RAY POWDER DIFFRACTION}

The XRPD reveals small differences among the four samples. A lump of the pattern between 18 and $33^{\circ} 2 \theta$ marks the presence of an amorphous phase, i.e. the glass (Fig. 4). Quartz, cristobalite, plagioclase and hematite are ubiquitous in all samples, whereas spinel occurs only in LP1, LP3b and LP8a. Peaks assigned to cordierite were identified in samples LP1 and LP3b. Clinopyroxene (probably fassaite) is present in LP3b. The intensity of the peaks points to the prevalence of quartz and cristobalite in samples LP8a and LP15, and of quartz, cristobalite and spinel in the samples LP1 and LP3b. The XRPD pattern for the sample LP3b, which is the most complete in terms of mineralogy, is displayed in Figure 4.

\section{ELECTRON MICROPROBE ANALYSIS}

The backscattered electron (BSE) images show, in all four samples, a more or less inhomogeneous glassy mass (e.g., Fig. 5), with spherical or elliptic voids and variable amount of mineral phases. The latter are $\mathrm{SiO}_{2}$ phases, plagioclase, hematite, spinel, ilmenite, rutile, cordierite, mullite and zircon. The vesicles occupy $\sim 40$ vol. $\%$ of the slag, the glass is $\sim 35 \mathrm{vol} . \%$, the $\mathrm{SiO}_{2}$ phases fill in $\sim 20 \mathrm{vol} . \%$ and the rest of $\sim 5 \mathrm{vol} . \%$ are other minerals.

Some of the measured compositions have significantly low totals and do not match that of known minerals. Two reasons might be responsible for the low totals, in particular of Fe, FeTi, FeSi and FeAlSi phases:

- extremely small grain size;

- their location close to the spherical vesicles surface.

The compositional misfit might also have two causes:

- electron beam reaches also other phases in the surroundings due to the small grain size;

- newly formed phases might incorporate foreign elements and keep them during cooling.

Having this in mind, the analyses can be taken only as a semi-quantitative account of the composition and therefore are not shown here. However, reasonable inferences can be made on at least some of them.

\section{MINERAL PHASES}

As the $\mathrm{SiO}_{2}$ phase occurs as quartz and $\alpha$-cristobalite - difficult to separate except by OM and XRPD (Figs. 3C, D and 4) - it is referred here as QC. They show several types of fissures 

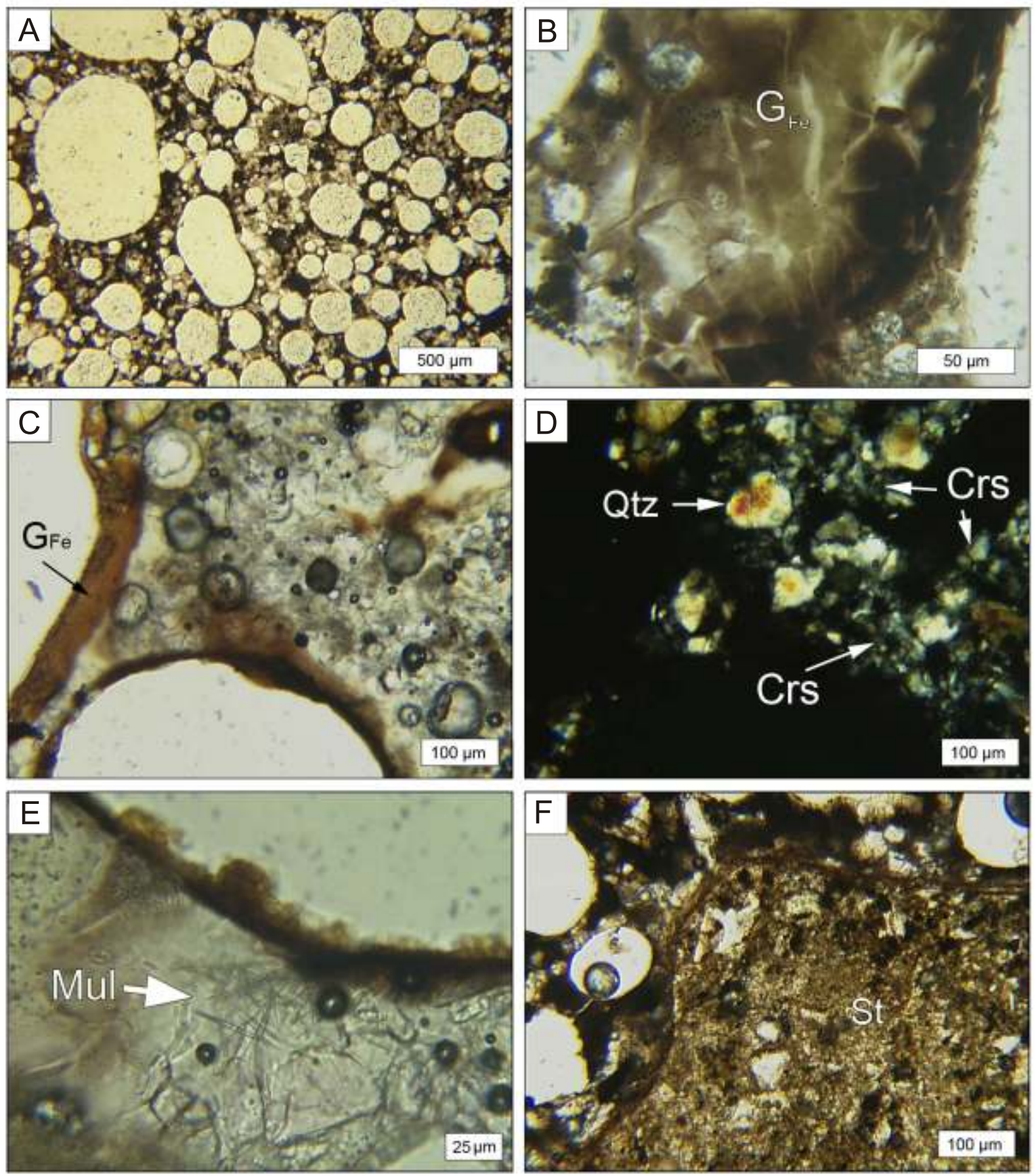

Fig. 3. Polarized light microphotos of the slags

A - vitreous body with rounded pores (sample LP1); $\mathbf{B}$ - detailed image of the brownish part $\left(\mathrm{G}_{\mathrm{Fe}}\right.$ ) of the glass (sample LP1); $\mathbf{C}$ - Fe-rich glass $\left(\mathrm{G}_{\mathrm{Fe}}\right)$ marked by a brown colour occurs around larger pores (sample LP15); D - quartz (Qtz) and $\alpha$-cristobalite (Crs) grains (sample LP15); E needle-like crystals of mullite (Mul) in the glass (sample LP15); F - siltstone (St) fragment, surrounded by a thin, brown, glassy reaction rim (sample LP1); seen with 1 polarizer (A-C, E, F) and crossed polarizers (D); mineral abbreviations according to Siivola and Schmid (2007) are used throughout the paper

(e.g., Fig. 5B). The first one occurs within the grains, the second continues into the surrounding glass. The third type, developed around QC grains as circular or elliptic fissures, is similar to the "perlitic cracks" shown by Grapes (2011).

Quartz and $\alpha$-cristobalite grains are mostly sub-angular to well-rounded and vary in size from $<10$ to $500 \mu \mathrm{m}$ (Fig. 5A, B).
The grain borders are partly sharp, partly transitional to the surrounding glassy mass. Sometimes very thin (few micrometres) rims around the QC grains are visible. In the BSE images the $\mathrm{SiO}_{2}$ phases are very well distinguishable from the glass by the more dark appearance due to their low average atomic number. However, no reliable distinction can be made among the $\mathrm{SiO}_{2}$ 


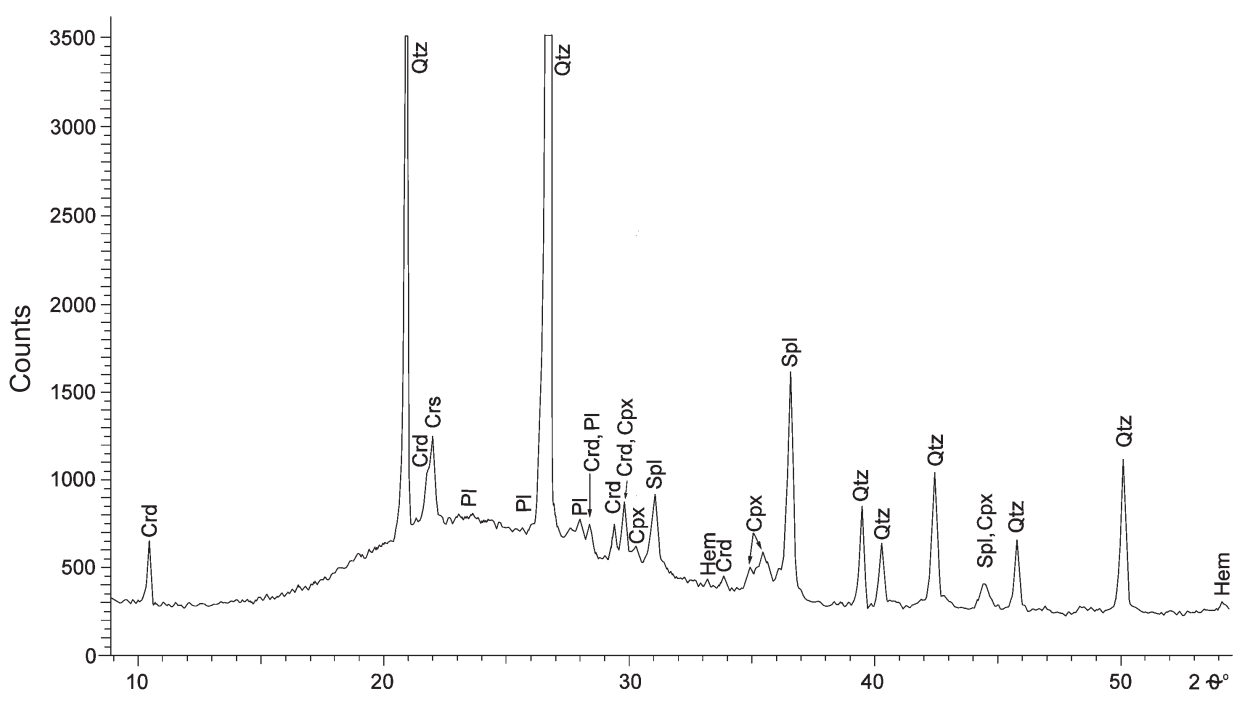

Fig. 4. X-ray powder diffraction expanded pattern, showing details for major and minor peaks (sample LP3b)

Cpx - clinopyroxene, Crd - (Fe-rich) cordierite, Crs - $\alpha$-cristobalite, Qtz - quartz, Hem - hematite, $\mathrm{Pl}$ - plagioclase, $\mathrm{Spl}$ - (magnetite-dominated) spinel

phases by EMPA. Some of quartz shows a slightly inhomogeneous appearance, with darkest parts of almost pure $\mathrm{SiO}_{2}$ and the more bright areas additionally containing $\mathrm{Al}, \mathrm{K}, \mathrm{Ca}, \mathrm{Fe}$ etc.

Plagioclase. The few feldspar grains which are found in the glass are plagioclases (Figs. 6, 7 and 8A), K-feldspar was not identified yet. The plagioclase grains are between 0.2 and $0.8 \mathrm{~mm}$ in size, their shape is rounded to elliptic. The composition and the according structural formulae are given in Table 1. The anorthite content varies from $\mathrm{An}_{38}$ (andesine) in the core, to $\mathrm{An}_{57}$ (labradorite) in the rim (Fig. 7). A weak oscillatory zoning is sometimes observed (Fig. 6A).

Plagioclase shows reaction textures at the contact with the glass. They extend from the margins of the feldspar grain into the centre and develop as parallel to sub-parallel aligned rods or platelets (Fig. 6). They consist of a very fine and intimate intergrowth of feldspar and glass, similar to the "fingerprint textures" described by Tsuchiyama and Takahashi (1983), Johannes (1989), and discussed by Grapes (2011). The spacing between the "platelets" is approximately 5-10 $\mu \mathrm{m}$. The glass within platelets is not homogeneous but consists of a fine network of inhomogeneous grey patches $(<1-2 \mu \mathrm{m})$ and bright, probably Fe-rich tiny particles (Fig. 6B). In the BSE images the glass appears in general slightly brighter than the solid plagioclase. This glass is depleted in $\mathrm{Na}_{2} \mathrm{O}, \mathrm{CaO}$ and $\mathrm{Al}_{2} \mathrm{O}_{3}$ but significantly enriched in $\mathrm{MgO}, \mathrm{K}_{2} \mathrm{O}$ and $\mathrm{FeO}$ relative to the plagioclase and contains often a significant amount of $\mathrm{P}_{2} \mathrm{O}_{5}$ (compare the composition of the "common glass" and "Ca-rich glass" groups in Tables 2 and 3 with the plagioclase composition in Table 1).

A slightly different pattern of melting appears in sample LP8a (Fig. 8A). The plagioclase has an elliptic shape and an inhomogeneous patchy composition (minimum $\mathrm{An}_{44}$ and maximum $\mathrm{An}_{58}$ ). It is surrounded by a $5-20 \mu \mathrm{m}$ thick glass zone with a few platelets intruding into the plagioclase. At the outer rim, this glass zone is intergrown with very thin parallel ori- ented more Fe-rich platelets resulting in a stripped pattern similar to the "fingerprint texture" described above. Outside this $20 \mathrm{~mm}$ wide glass zone follows a very inhomogeneous area with up to $50 \mu \mathrm{m}$ large elliptic "rafts" with a composition of the "Ca-rich glass". They are surrounded by a $1 \mu \mathrm{m}$ thin "Fe-rich glass" and embedded in an inhomogeneous spotty glass. The long axis of the rafts is in many cases directed in a high angle away from the plagioclase. The plagioclase itself is also inhomogeneous.

Fe-Ti oxides. Several opaque minerals were identified in the slags: $\mathrm{TiO}_{2}$ phase (referred here as rutile), ilmenite and magnetite-dominated spinel. They are 20-50, maximum $100 \mu \mathrm{m}$ in size (Figs. 5A, B; 8B and 9A-C). Most of the rutile grains are still coherent but they are in part already affected by melting. Under larger magnification it becomes clear that they are transformed into a porous network of Fe- and/or Ti-predominant phases (Fig. 8B). The rims are not smooth anymore but rather serrate due to the incipient melting. Rutile includes, besides some $\mathrm{FeO}$, small amounts of $\mathrm{MgO}$ and $\mathrm{Al}_{2} \mathrm{O}_{3}$.

Spinel forms tiny grains spread in the glass (Fig. 9A) or deposited on vesicles walls. Its identification is based on $\mathrm{OM}$, XRPD and the ratio between the main elements which were determined by EDS. However, the high Fe content suggests a magnetite-dominated spinel. All spinels contain some $\mathrm{SiO}_{2}$. The spinels in the glass have a size of 50 to $100 \mu \mathrm{m}$, whereas those deposited in the pores are smaller, around 2-3 $\mu \mathrm{m}$. They are chemically similar. Occasionally, an Fe-rich phase formed skeletal crystals, as shown in Figure 5B. Due to its small size, no reliable point analyses were possible.

The FeSi compounds occur in two different modes: a) as very small $(\sim 1-3 \mu \mathrm{m})$ grains with short prismatic or tabular habitus (Fig. 9D) often at the edge of more or less well-rounded pores, rarer within the glass, or b) as massive concentric filling in the spherical pores (Fig. 9B). The FeSi compounds consist essentially of only two major oxides, $\mathrm{SiO}_{2}$ and $\mathrm{FeO}$, both with a 

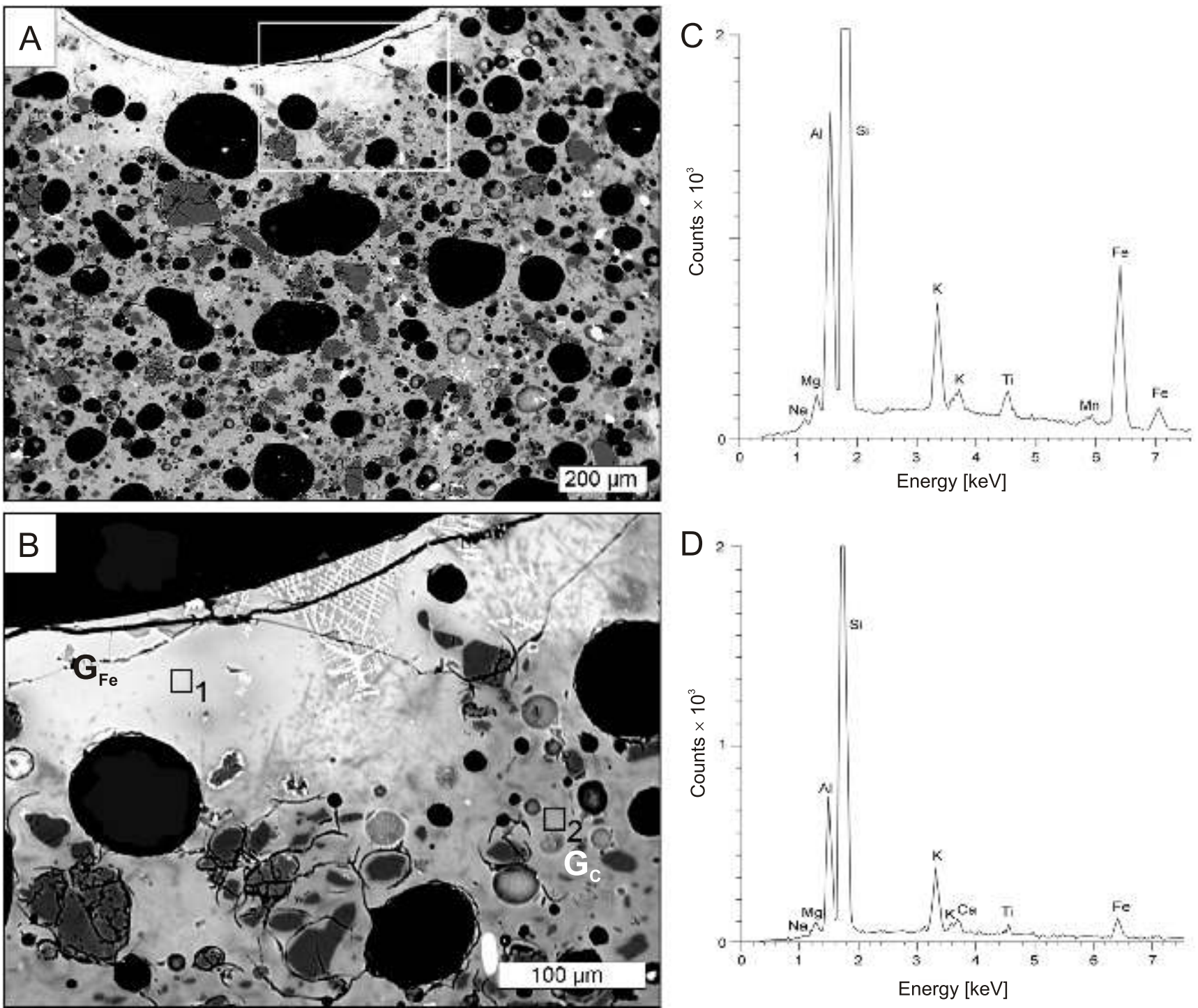

Fig. 5. BSE images of sample LP3b

A - general view of a porous glassy mass with abundant quartz grains (dark grey) and concentration of Fe (bright hue) towards the rim of a large vesicle (in black). The white spots are ilmenite, Ti-magnetite, zircon or spinel. The area marked with a white rectangle is shown enlarged in Figure 5B; $\mathbf{B}$ - detailed image of "Fe-rich glass" $\left(\mathrm{G}_{\mathrm{Fe}}\right)$ and "common glass" $\left(\mathrm{G}_{\mathrm{c}}\right)$. Note the Fe-rich skeletal crystals towards the pore wall and the cracks within and around QC grains (dark grey). The open black squares no. 1 and 2 mark the location of collected EDS spectra shown in Figure 5C, D. The bright spot is ilmenite; $\mathbf{C}-$ EDS spectrum of "Fe-rich glass"; D - EDS spectrum of "common glass"

wide compositional range, exhibiting negative correlation. This group represents probably Si-bearing hematite (Fig. 9B, C), fayalite and ferrosilite.

The FeAlSi phases occur a) as small crystallites (1-3 $\mu \mathrm{m})$ together with $\mathrm{FeSi}$ compounds and spinel, lining the inside wall of the vesicles, and b) intimately intergrown with glass, forming together rectangular pseudomorphs, $50-100 \mu \mathrm{m}$ in length. The FeAlSi phases consist essentially of a wide range of $\mathrm{SiO}_{2}$, $\mathrm{FeO}$ and $\mathrm{Al}_{2} \mathrm{O}_{3} \cdot \mathrm{K}_{2} \mathrm{O}$ and $\mathrm{Na}_{2} \mathrm{O}$ occur additionally. Potential minerals in this system are almandine, Fe-bearing cordierite (sekaninaite), clinopyroxene, Fe-rich staurolite, Fe-rich chloritoid, Fe-rich chlorite and Fe-rich biotite. None of these Fe-rich minerals would fit to our data with the exception of two points having a composition close to an Fe-rich chlorite but with a relatively high amount of $\mathrm{Na}$ and $\mathrm{K}$. Nevertheless, the XRPD (Fig. 4) indicates the presence of cordierite and clinopyroxene in small amounts.

AlSi phase. In some vesicles, tiny needle-like crystals $<1 \mu \mathrm{m}$ in thickness and $20-30 \mu \mathrm{m}$ in length were found (Fig. 9D). Due to the very small size and their location on the concave surface of the spherical pores, the obtained EMPA data are ambiguous. Nevertheless, the EDS spectra clearly show the predominance of $\mathrm{Al}$ and $\mathrm{Si}$, with some participation of Fe. As such needles were observed also by optical microscopy (Fig. 3E), we might suppose the presence of mullite.

Other minerals. An Fe-phosphate (most likely vivianite) was identified as forming a thick layer deposited in some of the large pores (Fig. 9C). 

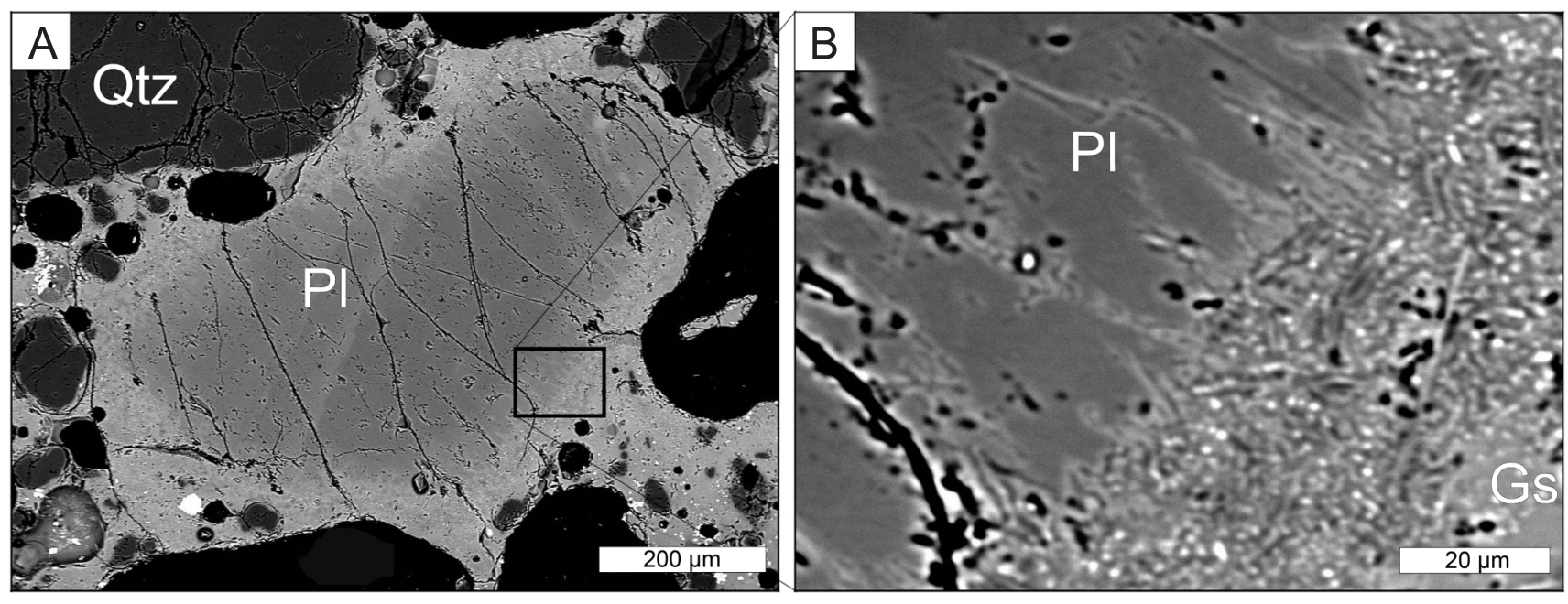

Fig. 6A - BSE image of a partially melted plagioclase grain (slightly zoned; sample LP1)

A - marked rectangle area is shown enlarged in Figure 6B; B - detailed image of the contact zone with "fingerprint texture" developed between plagioclase and glass (Gs); the bright spots are Fe-rich small grains; Pl - plagioclase, Qtz - quartz; the black areas are pores

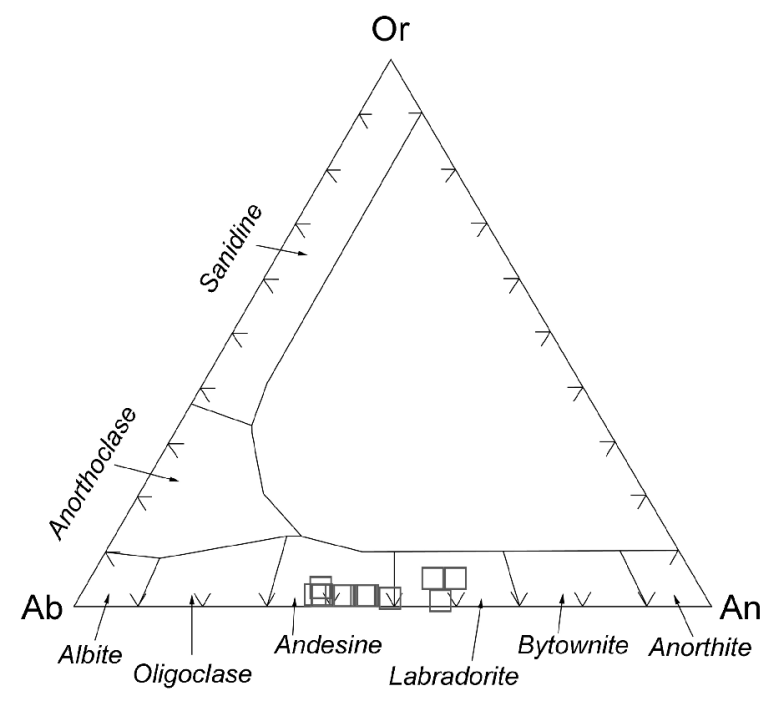

Fig. 7. Plot of the EMPA data of plagioclase in the classification diagram

\section{GLASS}

Glass is the most important and voluminous phase in the slag. Regarding only the solid phases, its fraction ranges from 48 to 64 vol. \%, with an average of 55 vol.\%. It has a wide range of compositions (Tables 2-4). The sum of the element oxides in EMPA is very close to $100 \mathrm{wt} . \%$ indicating that only a low amount of fluids remained dissolved in the glass, as most of it left the system upon firing. The $\mathrm{SiO}_{2}$ content varies from $\sim 49$ to $\sim 76$ wt.\%. The glass has a relatively high $\mathrm{Al}$ and $\mathrm{K}$ content, with traces of $\mathrm{Fe}, \mathrm{Ti}, \mathrm{Mg}$ and $\mathrm{Na}$.

The glasses can be grouped based on the enrichment in one oxide into: a high $\mathrm{Al}_{2} \mathrm{O}_{3}$ ("Al-rich glass"), a high $\mathrm{FeO}$ ("Fe-rich glass"), high $\mathrm{CaO}$ ("Ca-rich glass"), high $\mathrm{K}_{2} \mathrm{O}$ (“K-rich glass"),
$\mathrm{T}$ a b 1 e 1

Selected microprobe analyses (wt.\%) and calculated structural formulae for plagioclase (end-members in mol.\%)

\begin{tabular}{|c|c|c|c|c|c|c|}
\hline 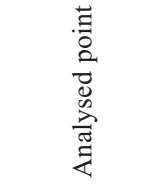 & $\frac{\stackrel{m}{\sim}}{\stackrel{1}{a}}$ & $\frac{\stackrel{+}{a}}{\stackrel{1}{\Delta}}$ & $\frac{\tilde{c}}{\stackrel{\sim}{d}}$ & $\frac{\vec{a}}{\stackrel{1}{a}}$ & 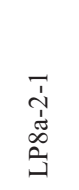 & 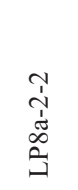 \\
\hline $\mathrm{SiO}_{2}$ & 60.17 & 57.26 & 59.78 & 57.65 & 56.19 & 52.94 \\
\hline $\mathrm{Al}_{2} \mathrm{O}_{3}$ & 26.57 & 28.25 & 26.86 & 26.59 & 27.49 & 29.20 \\
\hline $\mathrm{TiO}_{2}$ & $<\mathrm{dl}$ & $<\mathrm{dl}$ & $<\mathrm{dl}$ & 0.04 & $<\mathrm{dl}$ & $<\mathrm{dl}$ \\
\hline $\mathrm{FeO}$ & 0.18 & 0.26 & 0.20 & 0.39 & 0.23 & 0.27 \\
\hline $\mathrm{MnO}$ & $<\mathrm{dl}$ & $<\mathrm{dl}$ & $<\mathrm{dl}$ & 0.04 & $<\mathrm{dl}$ & 0.03 \\
\hline $\mathrm{MgO}$ & $<\mathrm{dl}$ & $<\mathrm{dl}$ & $<\mathrm{dl}$ & 0.18 & 0.02 & 0.02 \\
\hline $\mathrm{BaO}$ & $<\mathrm{dl}$ & 0.09 & $<\mathrm{dl}$ & $<\mathrm{dl}$ & $<\mathrm{dl}$ & $<\mathrm{dl}$ \\
\hline $\mathrm{CaO}$ & 7.63 & 9.74 & 8.39 & 9.65 & 9.17 & 11.65 \\
\hline $\mathrm{Na}_{2} \mathrm{O}$ & 6.73 & 5.59 & 6.44 & 4.08 & 6.15 & 4.74 \\
\hline $\mathrm{K}_{2} \mathrm{O}$ & 0.35 & 0.24 & 0.29 & 0.74 & 0.27 & 0.19 \\
\hline Total & 101.63 & 101.43 & 101.96 & 99.36 & 99.52 & 99.04 \\
\hline $\mathrm{Si}$ & 5.28 & 5.07 & 5.24 & 5.19 & 5.07 & 4.84 \\
\hline $\mathrm{Al}$ & 2.74 & 2.95 & 2.77 & 2.82 & 2.92 & 3.14 \\
\hline $\mathrm{Ti}$ & 0.00 & 0.00 & 0.00 & 0.00 & 0.00 & 0.00 \\
\hline $\mathrm{Fe}^{2+}$ & 0.01 & 0.02 & 0.01 & 0.03 & 0.02 & 0.02 \\
\hline $\mathrm{Mn}$ & 0.00 & 0.00 & 0.00 & 0.00 & 0.00 & 0.00 \\
\hline $\mathrm{Mg}$ & 0.00 & 0.00 & 0.00 & 0.02 & 0.00 & 0.00 \\
\hline $\mathrm{Ba}$ & 0.00 & 0.00 & 0.00 & 0.00 & 0.00 & 0.00 \\
\hline $\mathrm{Ca}$ & 0.72 & 0.92 & 0.79 & 0.93 & 0.89 & 1.14 \\
\hline $\mathrm{Na}$ & 1.14 & 0.96 & 1.09 & 0.71 & 1.08 & 0.84 \\
\hline $\mathrm{K}$ & 0.04 & 0.03 & 0.03 & 0.09 & 0.03 & 0.02 \\
\hline Total cations & 9.93 & 9.95 & 9.93 & 9.79 & 10.01 & 10.00 \\
\hline $\mathrm{Ab}$ & 60.2 & 50.2 & 57.2 & 41.2 & 53.9 & 41.9 \\
\hline An & 37.7 & 48.4 & 41.1 & 53.9 & 44.5 & 56.9 \\
\hline Or & 2.1 & 1.4 & 1.7 & 4.9 & 1.6 & 1.2 \\
\hline
\end{tabular}

$\mathrm{Fe}_{\mathrm{TOT}}$ as $\mathrm{FeO}$; calculation on a $16 \mathrm{O}$ basis; $<\mathrm{dl}-$ below detection limit 

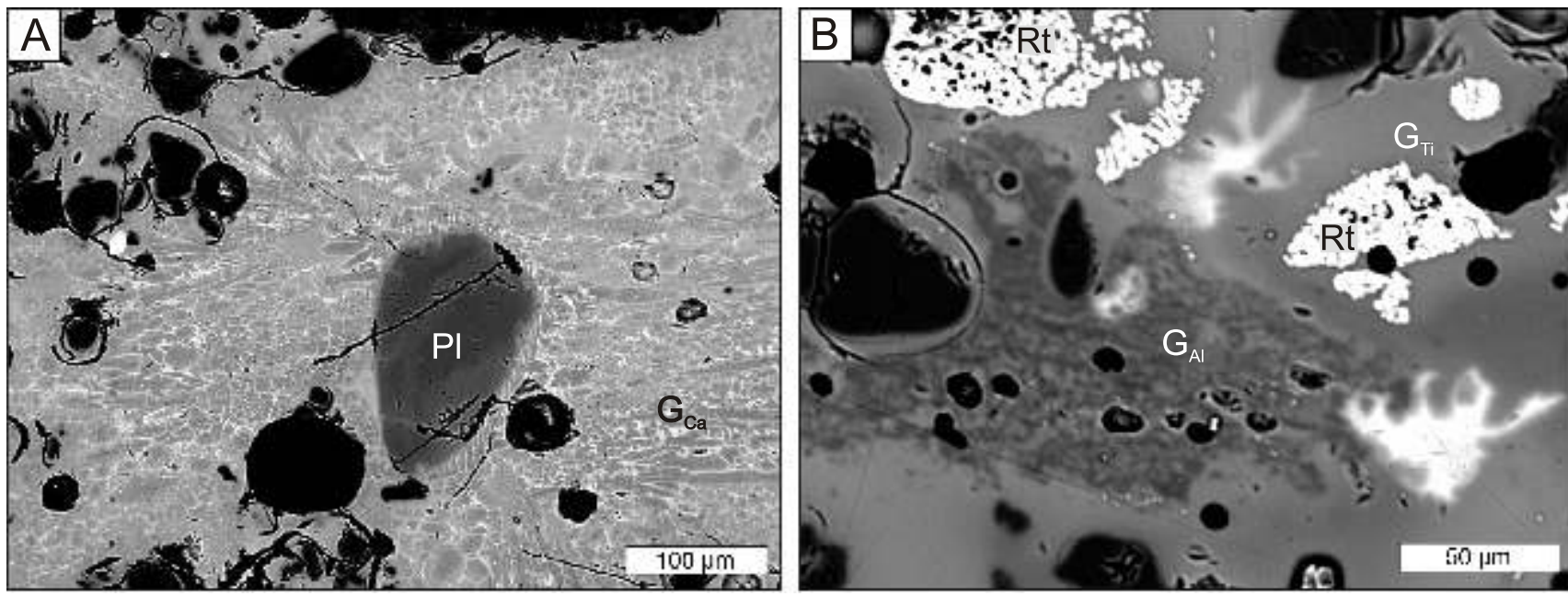

Fig. 8. BSE images of "Ca-rich glass" $\left(G_{\mathrm{Ca}}\right)$, "Al-rich glass" $\left(G_{\mathrm{Al}}\right)$ and "Ti-rich glass" $\left(\mathrm{G}_{\mathrm{Ti}}\right)$ in sample LP8a

A - inhomogeneous plagioclase (Pl): dark parts have more $\mathrm{Na}$, the lighter have more $\mathrm{Ca}$; plagioclase is surrounded by a thin layer of glass and radial-oriented melt structures (dark elongated areas with bright rims) of "Ca-rich glass"; B - "Al-rich glass" and "Ti-rich glass"; melting of rutile (Rt)

high $\mathrm{MgO}$ ("Mg-rich glass"), and a high $\mathrm{TiO}_{2}$ ("Ti-rich glass") group, respectively. The remaining group, the largest one, has no specific enrichment or depletion in any of the oxides and will be termed here "common glass". The glass groups are graphically depicted in Figure 10. According to the random measuring, some of these groups, i.e. "Al-rich" and "Ti-rich glass", comprise only two analyses.

The "common glass" (Table 2) contains $\mathrm{SiO}_{2}$ from 58 to 76 wt.\% (Fig. 10A), $\mathrm{CaO}$ from 0.5 to 3.5 wt.\% (Fig. 10A), $\mathrm{K}_{2} \mathrm{O}$ from 2 to 4 wt.\% (Fig. 10B), FeO from 1 to $7 \mathrm{wt} . \%$ (Fig. 10C), $\mathrm{Al}_{2} \mathrm{O}_{3}$ from 8 to 25 wt.\% (Fig. 10D) and $\mathrm{MgO}$ from 1 to 3 wt. $\%$. The $\mathrm{SiO}_{2}$ shows a weak negative correlation with $\mathrm{Al}_{2} \mathrm{O}_{3}, \mathrm{MgO}$ and $\mathrm{FeO}$. This compositional variability is reflected in the change of brightness in the BSE images (Fig. 5A, B).

Among the enriched groups, the "CaO-rich glass" (Table 3) is found in the surroundings of plagioclase (Fig. 8). This glass has $\mathrm{SiO}_{2}$ between 57 and 60 wt. $\%$ and $\mathrm{Al}_{2} \mathrm{O}_{3}$ between 18 and 21 wt. $\%$. $\mathrm{CaO}$ is high, up to 8 wt. $\%$ whereas $\mathrm{Na}_{2} \mathrm{O}$ and $\mathrm{K}_{2} \mathrm{O}$ are low, with 2 and $\sim 3 \mathrm{wt} . \%$ respectively. The composition of this glass is heterogeneous, forming some rafts which point with their long axis radial away from the plagioclase remnants (Fig. 8A).

The "K-rich glass" (Table 3 and Fig. 10B) shows $\mathrm{SiO}_{2}$ and $\mathrm{Al}_{2} \mathrm{O}_{3}$ in the range of a common $\mathrm{K}$-feldspar, i.e. 61-66.5 wt.\% and $17-19 \mathrm{wt} . \%$ respectively. The $\mathrm{K}_{2} \mathrm{O}$ with 5-7.5 wt. $\%$ is low for a K-feldspar. Additionally, there is a certain amount of $\mathrm{CaO}, \mathrm{MgO}$ and $\mathrm{FeO}$.

The "Fe-rich glass" contains $\mathrm{FeO}$ between $\sim 9$ and $\sim 15$ wt. $\%$ (Table 4 and Fig. 10C). This type of glass, which can be easily distinguished in the BSE images by its relative brightness compared to common glass, is concentrated along smaller and larger pores (Fig. 5A, B). The highest FeO concentration is found directly along the edge of the voids and vesicles and diminishes away from the rims (Fig. 5C, D). Associated with the Fe-rich zone are Fe-rich oxides and Fe-rich silicates.

The "Ti-rich" and "Mg-rich" groups of glass (Table 4) occur in areas with a fairly homogeneous composition and are not in direct contact with any minerals. However, the "Ti-rich glass" is so far found only in the vicinity of the $\mathrm{TiO}_{2}$ phase (rutile) showing signs of melting (Fig. 8B). No high $\mathrm{Mg}$ phase was detected in the surrounding of the "Mg-rich glass".

In the BSE images, the "Al-rich glass" appears as dark areas, up to $50 \mu \mathrm{m}$ in size, which are partly homogeneous or inhomogeneous, separated by more bright glass compositions (Fig. 8B). $\mathrm{SiO}_{2}$ ranges from 49 to 51 wt. $\%, \mathrm{Al}_{2} \mathrm{O}_{3}$ from $35-42$ wt. $\%, \mathrm{FeO}$ from 4.2 to 4.5 wt. $\%, \mathrm{TiO}_{2}$ between 0.2 and 1.4 wt. $\%, \mathrm{MgO}$ between 0.8 and 1.3 wt. $\%, \mathrm{CaO}$ from 0.2 to 2 wt. $\%, \mathrm{Na}_{2} \mathrm{O}$ from 0.4 to 1.1 wt. $\%$ and $\mathrm{K}_{2} \mathrm{O}$ between 1.3 and 3 wt.\% (Table 4 and Fig. 10D). The dark colour of this glass type is due both to the higher amount of $\mathrm{Al}$ (up to 2-2.5 times) and the lower amount of $\mathrm{Si}, \mathrm{Ca}, \mathrm{Fe}, \mathrm{Mg}, \mathrm{K}$ and $\mathrm{Ti}$ than most of the other glasses (Tables 2-4).

\section{DISCUSSION}

\section{NATURE AND ORIGIN OF SLAGS}

The identification of slag origin in various archaeological environments is a difficult task. As shown in the introductory part, there is a wide range of possible raw materials for slags, from ore, adobe bricks and soil, to kiln clayey walls or pot load. Accordingly, the main problem of Lăpuş slag pieces is related with their origin.

The shape and the composition of our slag pieces do not support a relation to metal smelting (see e.g., Serneels, 1995; Serneels and Crew, 1997; Buchwald and Wivel, 1998; Anderson et al., 2003; Degryse et al., 2003; Rehren et al., 2007, 2012; Kierczak and Pietranik, 2011; Sharp and Mittwede, 2011). If they would have been result of e.g., iron processing, they should have 35-75 wt.\% FeO (Buchwald and Wivel, 1998) and would contain high amounts of $\mathrm{Fe}$ silicates. But the latter are rare in our samples and restricted to the Fe-rich areas around the pores. The 

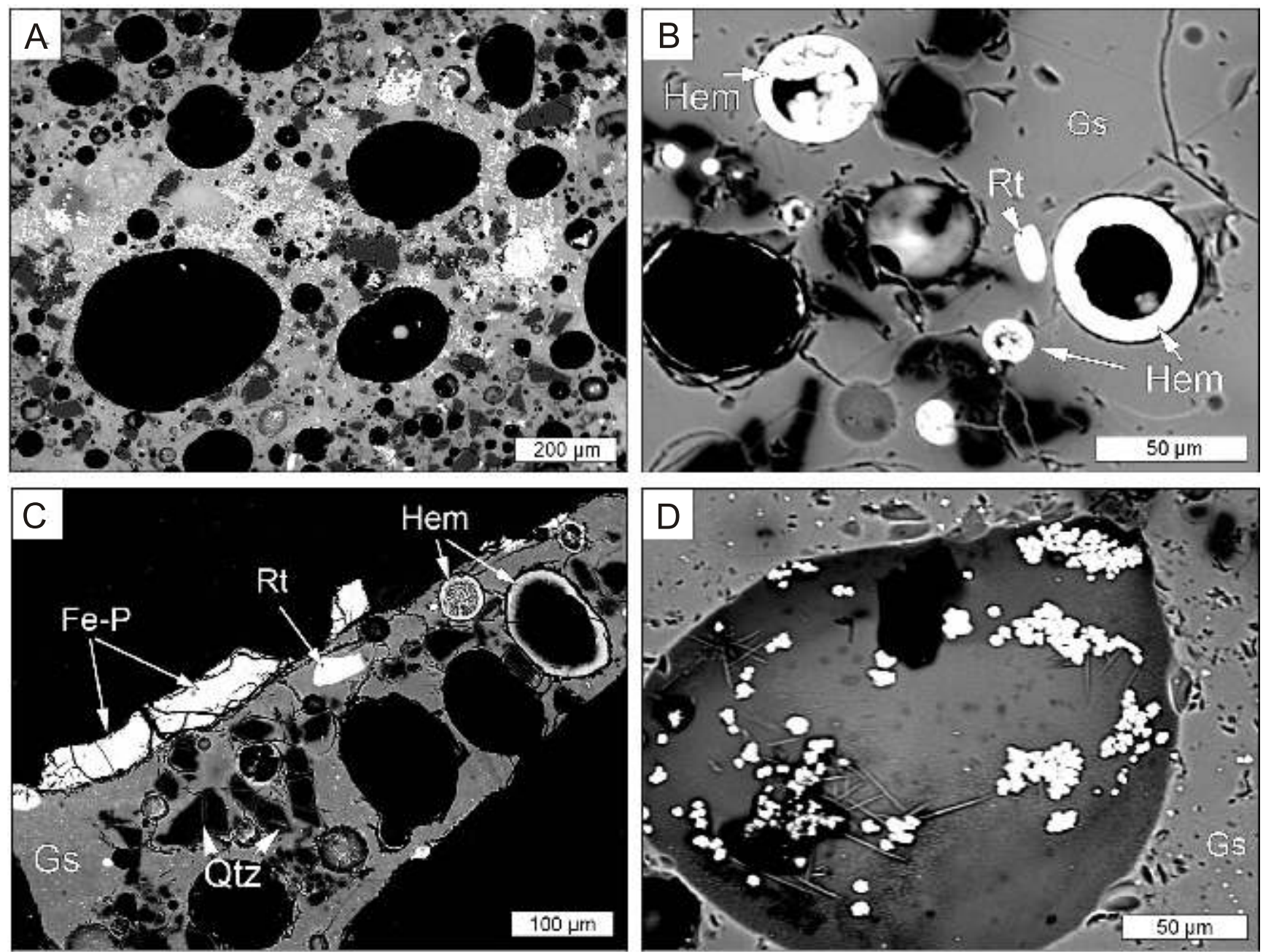

Fig. 9. BSE images of relict and newly formed phases

A - uneven concentration of spinel (small white spots) and $\mathrm{SiO}_{2}$ phase (dark grey) in the vitreous mass (light grey); rounded black areas are pores (sample LP3b); B - hematite, rutile and quartz in glass; hematite is lining the rounded pores (sample LP8a); $\mathbf{C}$ - thin layers of Fe-phosphate (Fe-P) and hematite lining the large and the small pores, respectively (sample LP8a); D - precipitation of the FeSi phase (white spots) and AlSi phase (needle-like mullite) within the pore (sample LP15); Hem - hematite, Rt - rutile, Qtz - quartz, Gs - glass

same is true for other metals smelting, which would produce slags with a high amount of according metals.

However, even if completely deformed and partly glassy, some of the Lăpuş shards are recognizable as former ceramic vessels (Fig. 2B). This implies that the remains had been fired twice: once to manufacture the ceramic vessels and a second time in a large fire at very high temperatures. The actual composition of the slag includes four types of constituents: a) relic minerals, most showing signs of melting, b) newly formed mineral phases, c) glass, and d) post-depositional phase.

The melting process is very advanced, as evidenced by approximately the $55 \mathrm{vol} . \%$ of glass related to the solid phases i.e. without pores (see Chapter Glass). The only primary minerals preserved are quartz (surrounded by glassy rims), very rare plagioclase (partially melted) and some accessory heavy minerals such as rutile, zircon, ilmenite and spinel. All other minerals which might have been in the original material, e.g., clay minerals, micas, K-feldspar etc. were completely transformed into glass.
Quartz prevails in the slag as mineral phase. The XRPD did not identify any $\beta$-quartz and tridymite. Plagioclase with similar characteristics as those from the slags, i.e. oscillatory zoning, was described from the Neogene basaltic andesite from the Baia Mare area, NW of Lăpus (Jurje, 2012). The plagioclase in the slags originated most likely from similar volcanics, which occur at few $\mathrm{km} \mathrm{NE}$ of the site and are crosscut by the Lăpuş River (Fig. 1). It was probably included as temper in the original pots.

Cristobalite, hematite, spinel, cordierite, clinopyroxene, fayalite, ferrosilite and mullite are phases formed due to the second firing and subsequent cooling. Cristobalite occurs on the expenses of primary quartz. Hematite fills in well-rounded pores. The newly formed spinel is found unevenly distributed, mainly at the edge or on the inner wall of the vesicles.

Various groups of glass reflect the inhomogeneity and the incomplete mixing of the melt. "Ca-rich" and "Ti-rich glass" were found in the vicinity of mineral phases with related composition. Nevertheless, the "Ca-rich glass" is depleted in $\mathrm{CaO}$ 


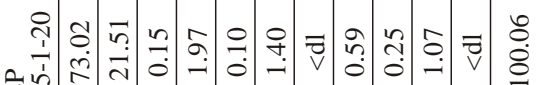 $\mathrm{K}_{2} \mathrm{O}, \mathrm{FeO}, \mathrm{MgO}$ and $\mathrm{P}_{2} \mathrm{O}_{5}$.}

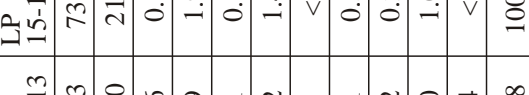

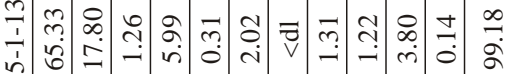

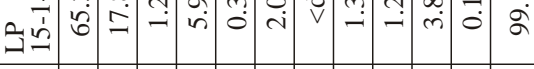

ㅇำ กี

근

읭ำ

西皇

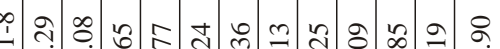

光光

立

光皇



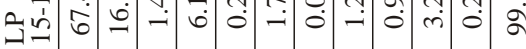

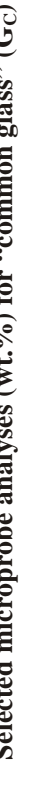

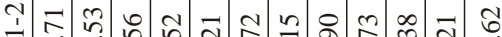

元皇

근 范

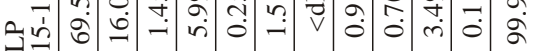

只

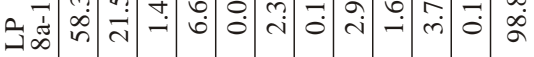

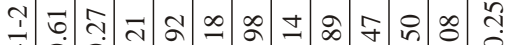

च

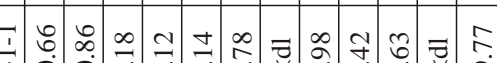

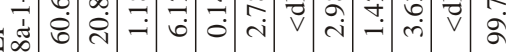

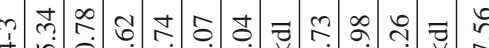

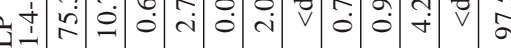

స ำ

मे

$\exists$ ๆ

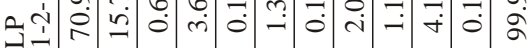

ลิ

Gu

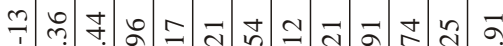

च.

$\exists \tilde{7}$

ப.

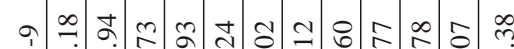

دu

m.

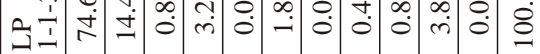

ㄱำ

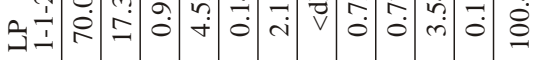

D

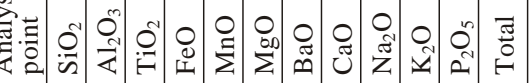

compared with the solid plagioclase, but variably enriched in

Kaolinite (metakaolinite) and/or muscovite must have contributed to the rare "Al-rich glass" (at the same time poor in $\mathrm{Si}$ ) upon melting, whereby the melt was not homogenized with the rest but remained to a large part at the place of the original minerals. Up to now, no K-feldspar remnants were identified but this mineral could have been the source for the "K-rich glass". Only few spots within the glass show a relatively high $\mathrm{K}_{2} \mathrm{O}$ and an appropriate $\mathrm{SiO}_{2}$ (>60 wt.\%) and $\mathrm{Al}_{2} \mathrm{O}_{3}$ (17 to $19 \mathrm{wt} . \%$ ) content. This suggests that the melt was derived from a previous $\mathrm{K}$-feldspar (see also section on the " $\mathrm{K}_{2} \mathrm{O}$-rich glass" and Table 3).

The composition of the "common glass" is close to that of other Bronze Age ceramics found elsewhere in the Transylvanian Basin, e.g., in Derşida, Copăceni or Palatca, which are believed to derive from Ca-poor illitic sediments (Hoeck et al., 2009).

The origin of vivianite is unclear but it might be regarded rather as a post-depositional i.e. burial contamination (see also Freestone et al., 1985, 1994; Maggetti, 2001; Maritan and Mazzoli, 2004; McGowan and Prangnell, 2006; Maritan et al., 2009) rather than a fuel ash contribution (Blakelock et al., 2009).

We do not find many mineralogical hints on the original composition of the ceramic paste. The only information comes from chemical composition. With an amount of $\mathrm{SiO}_{2}$ between $\sim 70$ and $~ 75$ wt.\% (unpublished ICP-MS data), the slag chemistry strongly points to a predominantly siliceous composition. The original paste for the pots originated most likely from quartz-rich silt amended with some larger quartz/quartzite and feldspar as temper.

\section{FIRING TEMPERATURE}

As shown above, the slags obviously show a two-stage firing process. The second firing occurred at much higher temperature and obliterated all features resulted upon the first firing which took place in a bonfire or possibly a kiln. We found up to date no minerals which could be undoubtedly assigned to the first firing event generating the ceramic vessels. The vitreous nature of the slag implies a melt phase, followed by a fast cooling which prevented the recrystallisation of the glass. The mineral composition might also offer some clues regarding the maximum temperature attained.

The temperature of the second firing can be estimated on the pore structure and vitreous appearance basis. Typically, the Lăpuş slags consist of a coherent glassy mass with isolated, variably-sized, often spherical pores. Tite and Maniatis (1975) have shown by means of refiring samples and subsequent SEM studies that at $1050-1150^{\circ} \mathrm{C}$ the cellular pore structure coarsens successively and the amount of glass increases. At "total vitrification" only isolated pores remain. Depending on the firing condition and the composition of the paste, temperatures for this "total vitrification" might be as high as $1150^{\circ} \mathrm{C}$ (Tite and Maniatis, 1975). Zacharias et al. (2006) reported similar temperatures of above $1100^{\circ} \mathrm{C}$ based on the appearance of spherical pores in a more or less totally glassy groundmass. Accord- 
Selected microprobe analyses (wt.\%) for "Ca-rich glass" $\left(\mathrm{G}_{\mathrm{Ca}}\right)$ and "K-rich glass" $\left(\mathrm{G}_{\mathrm{K}}\right)$

\begin{tabular}{|c|c|c|c|c|c|c|c|c|c|c|c|c|c|c|c|c|}
\hline 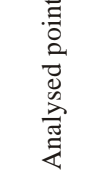 & $\begin{array}{l}\stackrel{0}{1} \\
\frac{1}{1} \\
\infty \\
\infty \\
a \\
a\end{array}$ & $\begin{array}{l}n \\
\stackrel{n}{1} \\
\frac{1}{\infty} \\
\infty \\
a \\
a\end{array}$ & $\begin{array}{l}0 \\
\frac{1}{1} \\
\frac{1}{1} \\
\infty \\
\infty \\
a \\
a\end{array}$ & 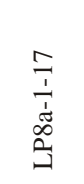 & 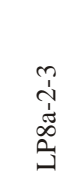 & 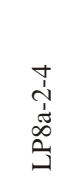 & 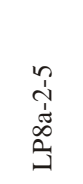 & 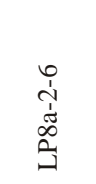 & 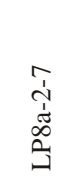 & 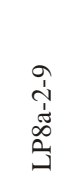 & 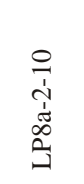 & 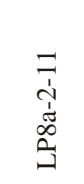 & 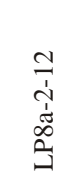 & 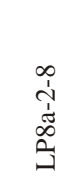 & 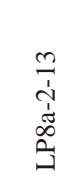 & 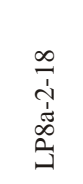 \\
\hline $\begin{array}{c}\text { Glass } \\
\text { type }\end{array}$ & $\mathrm{G}_{\mathrm{Ca}}$ & $\mathrm{G}_{\mathrm{Ca}}$ & $\mathrm{G}_{\mathrm{Ca}}$ & $\mathrm{G}_{\mathrm{Ca}}$ & $\mathrm{G}_{\mathrm{Ca}}$ & $\mathrm{G}_{\mathrm{Ca}}$ & $\mathrm{G}_{\mathrm{Ca}}$ & $\mathrm{G}_{\mathrm{Ca}}$ & $\mathrm{G}_{\mathrm{Ca}}$ & $\mathrm{G}_{\mathrm{Ca}}$ & $\mathrm{G}_{\mathrm{Ca}}$ & $\mathrm{G}_{\mathrm{Ca}}$ & $\mathrm{G}_{\mathrm{Ca}}$ & $\mathrm{G}_{\mathrm{K}}$ & $\mathrm{G}_{\mathrm{K}}$ & $\mathrm{G}_{\mathrm{K}}$ \\
\hline $\mathrm{SiO}_{2}$ & 59.42 & 60.62 & 60.13 & 60.05 & 56.58 & 57.87 & 57.12 & 57.41 & 58.49 & 57.43 & 57.08 & 58.32 & 58.02 & 63.49 & 61.25 & 66.42 \\
\hline $\mathrm{Al}_{2} \mathrm{O}_{3}$ & 19.32 & 18.62 & 18.97 & 19.05 & 19.24 & 18.10 & 19.31 & 20.60 & 19.69 & 18.51 & 20.31 & 19.44 & 20.84 & 16.76 & 17.67 & 19.13 \\
\hline $\mathrm{TiO}_{2}$ & 1.14 & 1.20 & 1.04 & 1.00 & 1.29 & 1.34 & 1.44 & 1.28 & 1.19 & 1.67 & 1.42 & 1.41 & 1.22 & 1.04 & 1.48 & $<\mathrm{dl}$ \\
\hline $\mathrm{FeO}$ & 7.22 & 6.52 & 6.76 & 6.60 & 6.13 & 5.58 & 5.18 & 4.13 & 4.07 & 7.24 & 4.84 & 4.67 & 4.70 & 3.99 & 6.67 & 0.73 \\
\hline $\mathrm{MnO}$ & 0.10 & 0.10 & 0.12 & 0.13 & 0.50 & 0.38 & 0.35 & 0.30 & 0.25 & 0.35 & 0.29 & 0.35 & 0.23 & 0.18 & 0.37 & 0.14 \\
\hline $\mathrm{MgO}$ & 2.73 & 2.71 & 2.63 & 2.66 & 2.44 & 2.68 & 2.40 & 1.66 & 1.79 & 3.71 & 2.65 & 3.15 & 2.15 & 1.55 & 2.44 & 0.73 \\
\hline $\mathrm{BaO}$ & $<\mathrm{dl}$ & $<\mathrm{dl}$ & $<\mathrm{dl}$ & 0.16 & 0.20 & $<\mathrm{dl}$ & $<\mathrm{dl}$ & 0.11 & $<\mathrm{dl}$ & 0.10 & 0.08 & $<\mathrm{dl}$ & $<\mathrm{dl}$ & 0.11 & 0.15 & 0.25 \\
\hline $\mathrm{CaO}$ & 4.85 & 4.37 & 4.36 & 4.47 & 6.91 & 6.89 & 7.03 & 7.78 & 8.16 & 5.01 & 6.71 & 6.91 & 6.93 & 3.54 & 2.31 & 2.94 \\
\hline $\mathrm{Na}_{2} \mathrm{O}$ & 1.30 & 1.34 & 1.26 & 1.33 & 2.06 & 1.76 & 2.01 & 2.17 & 1.98 & 1.51 & 1.85 & 1.83 & 1.87 & 0.74 & 0.92 & 1.21 \\
\hline $\mathrm{K}_{2} \mathrm{O}$ & 3.05 & 3.35 & 3.33 & 3.29 & 2.73 & 2.79 & 2.57 & 2.46 & 2.45 & 2.91 & 2.47 & 2.61 & 2.21 & 6.39 & 5.38 & 7.28 \\
\hline $\mathrm{P}_{2} \mathrm{O}_{5}$ & $<\mathrm{d} l$ & $<\mathrm{dl}$ & $<\mathrm{dl}$ & $<\mathrm{d} l$ & 0.92 & 0.97 & 0.89 & 0.69 & 0.79 & 0.71 & 0.86 & 0.75 & 0.77 & 0.42 & 0.47 & $<\mathrm{dl}$ \\
\hline Total & 99.13 & 98.83 & 98.60 & 98.74 & 99.00 & 98.36 & 98.30 & 98.59 & 98.86 & 99.15 & 98.56 & 99.44 & 98.94 & 98.21 & 99.11 & 98.83 \\
\hline
\end{tabular}

For explanation see Table 2

Selected microprobe analyses (wt.\%) for "Fe-rich glass" $\left(\mathbf{G}_{\mathrm{Fe}}\right)$, "Ti-rich glass" $\left(\mathrm{G}_{\mathrm{Ti}}\right)$, "Mg-rich glass" $\left(\mathbf{G}_{\mathrm{Mg}}\right)$ and "Al-rich glass" $\left(\mathbf{G}_{\mathrm{Al}}\right)$

\begin{tabular}{|c|c|c|c|c|c|c|c|c|c|c|c|c|c|c|c|}
\hline  & $\begin{array}{l}\frac{7}{d} \\
\frac{1}{n} \\
\frac{a}{a}\end{array}$ & $\frac{N}{\stackrel{1}{n}}$ & 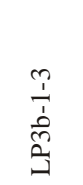 & $\frac{\infty}{\frac{1}{a}}$ & $\begin{array}{l}m \\
\frac{1}{d} \\
\infty \\
\infty \\
a\end{array}$ & 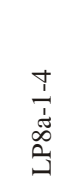 & $\frac{\hat{r}}{\frac{1}{a}}$ & $\frac{0}{\infty}$ & $\frac{\vec{r}}{\dot{d}}$ & $\frac{\stackrel{+}{+}}{\stackrel{+}{a}}$ & $\frac{\frac{1}{1}}{\frac{1}{a}}$ & $\frac{\vec{n}}{\frac{1}{a}}$ & $\frac{\tilde{r}}{\frac{1}{a}}$ & $\frac{n}{\frac{n}{1}}$ & $\begin{array}{l}a \\
\frac{1}{d} \\
\dot{\infty} \\
a \\
a\end{array}$ \\
\hline $\begin{array}{l}\text { Glass } \\
\text { type }\end{array}$ & $\mathrm{G}_{\mathrm{Fe}}$ & $\mathrm{G}_{\mathrm{Fe}}$ & $\mathrm{G}_{\mathrm{Fe}}$ & $\mathrm{G}_{\mathrm{Fe}}$ & $\mathrm{G}_{\mathrm{Ti}}$ & $\mathrm{G}_{\mathrm{Ti}}$ & $\mathrm{G}_{\mathrm{Mg}}$ & $\mathrm{G}_{\mathrm{Mg}}$ & $\mathrm{G}_{\mathrm{Mg}}$ & $\mathrm{G}_{\mathrm{Mg}}$ & $\mathrm{G}_{\mathrm{Mg}}$ & $\mathrm{G}_{\mathrm{Mg}}$ & $\mathrm{G}_{\mathrm{Mg}}$ & $\mathrm{G}_{\mathrm{Al}}$ & $\mathrm{G}_{\mathrm{Al}}$ \\
\hline $\mathrm{SiO}_{2}$ & 63.80 & 65.74 & 63.22 & 71.74 & 57.79 & 60.41 & 73.55 & 71.83 & 66.78 & 74.12 & 70.91 & 69.35 & 69.01 & 49.14 & 51.02 \\
\hline $\mathrm{Al}_{2} \mathrm{O}_{3}$ & 16.33 & 15.21 & 13.76 & 15.02 & 18.53 & 17.77 & 12.52 & 13.89 & 16.77 & 12.05 & 15.65 & 14.78 & 15.63 & 41.58 & 36.00 \\
\hline $\mathrm{TiO}_{2}$ & 1.29 & 1.30 & 1.27 & 1.16 & 6.15 & 5.38 & 0.51 & 0.53 & 0.53 & 0.75 & 0.98 & 0.60 & 0.46 & 0.29 & 1.43 \\
\hline $\mathrm{FeO}$ & 12.60 & \begin{tabular}{|l|}
11.18 \\
\end{tabular} & 14.25 & 8.53 & 6.48 & 5.75 & 4.00 & 4.67 & 5.21 & 3.52 & 3.85 & 5.18 & 5.74 & 4.41 & 4.30 \\
\hline $\mathrm{MnO}$ & 0.66 & 0.47 & 0.31 & 0.04 & 0.12 & 0.12 & 0.15 & 0.22 & 0.28 & 0.13 & 0.14 & 0.20 & 0.24 & 0.04 & 0.06 \\
\hline $\mathrm{MgO}$ & 1.89 & 1.55 & 1.00 & 0.84 & 1.88 & 1.65 & 3.26 & 3.53 & 5.50 & 3.33 & 2.87 & 4.77 & 4.31 & 0.83 & 1.28 \\
\hline $\mathrm{BaO}$ & $<\mathrm{dl}$ & $<\mathrm{dl}$ & 0.09 & 0.09 & 0.07 & $<\mathrm{dl}$ & $<\mathrm{dl}$ & $<\mathrm{dl}$ & 0.10 & $<\mathrm{dl}$ & $<\mathrm{dl}$ & $<\mathrm{dl}$ & $<\mathrm{dl}$ & $<\mathrm{dl}$ & 0.10 \\
\hline $\mathrm{CaO}$ & 0.67 & 0.57 & 0.31 & 0.10 & 2.22 & 1.96 & 0.66 & 0.86 & 0.73 & 0.65 & 0.61 & 0.73 & 0.80 & 0.17 & 1.78 \\
\hline $\mathrm{Na}_{2} \mathrm{O}$ & 0.91 & 0.71 & 0.97 & 0.07 & 1.33 & 1.28 & 0.58 & 0.74 & 0.73 & 0.89 & 0.81 & 0.83 & 0.76 & 0.41 & 1.15 \\
\hline $\mathrm{K}_{2} \mathrm{O}$ & 2.08 & 2.45 & 2.76 & 0.05 & 4.29 & 4.32 & 3.10 & 3.59 & 3.40 & 3.98 & 3.69 & 3.41 & 3.55 & 1.32 & 3.00 \\
\hline $\mathrm{P}_{2} \mathrm{O}_{5}$ & 0.09 & 0.08 & 0.10 & 0.53 & 0.11 & 0.14 & $<\mathrm{d} l$ & $<\mathrm{dl}$ & $<\mathrm{dl}$ & $<\mathrm{dl}$ & 0.19 & 0.13 & $<\mathrm{dl}$ & $<\mathrm{dl}$ & $<\mathrm{dl}$ \\
\hline Total & 100.32 & 99.26 & 98.04 & 98.17 & 98.97 & 98.78 & 98.33 & 99.86 & 100.03 & 99.42 & 99.70 & 99.98 & 100.50 & 98.19 & 100.12 \\
\hline
\end{tabular}

For explanations see Table 2

ing to Maritan et al. (2005), vitrification becomes important over $1000^{\circ} \mathrm{C}$.

In BSE images quartz is only slightly inhomogeneous, with darkest parts of almost pure $\mathrm{SiO}_{2}$ and the more bright areas additionally containing $\mathrm{Al}, \mathrm{K}, \mathrm{Ca}, \mathrm{Fe}$ etc. The latter can be interpreted as melted rims or places around quartz. A similar chemistry was observed in quartz from other Bronze Age ceramics from Romania, e.g., Ilişua and Cucuteni sites (Ionescu and Hoeck, 2011; Ionescu et al., 2011). There, it shows a linear dependence between $\mathrm{SiO}_{2}$ and other oxides. In the Lăpuş slag glass no such co-variation is visible, the element distribution is rather random. An alternative interpretation could be that these are remains of high-temperature $\mathrm{SiO}_{2}$ phases, such as $\alpha$-cristobalite, which might incorporate a much higher amount of for- 

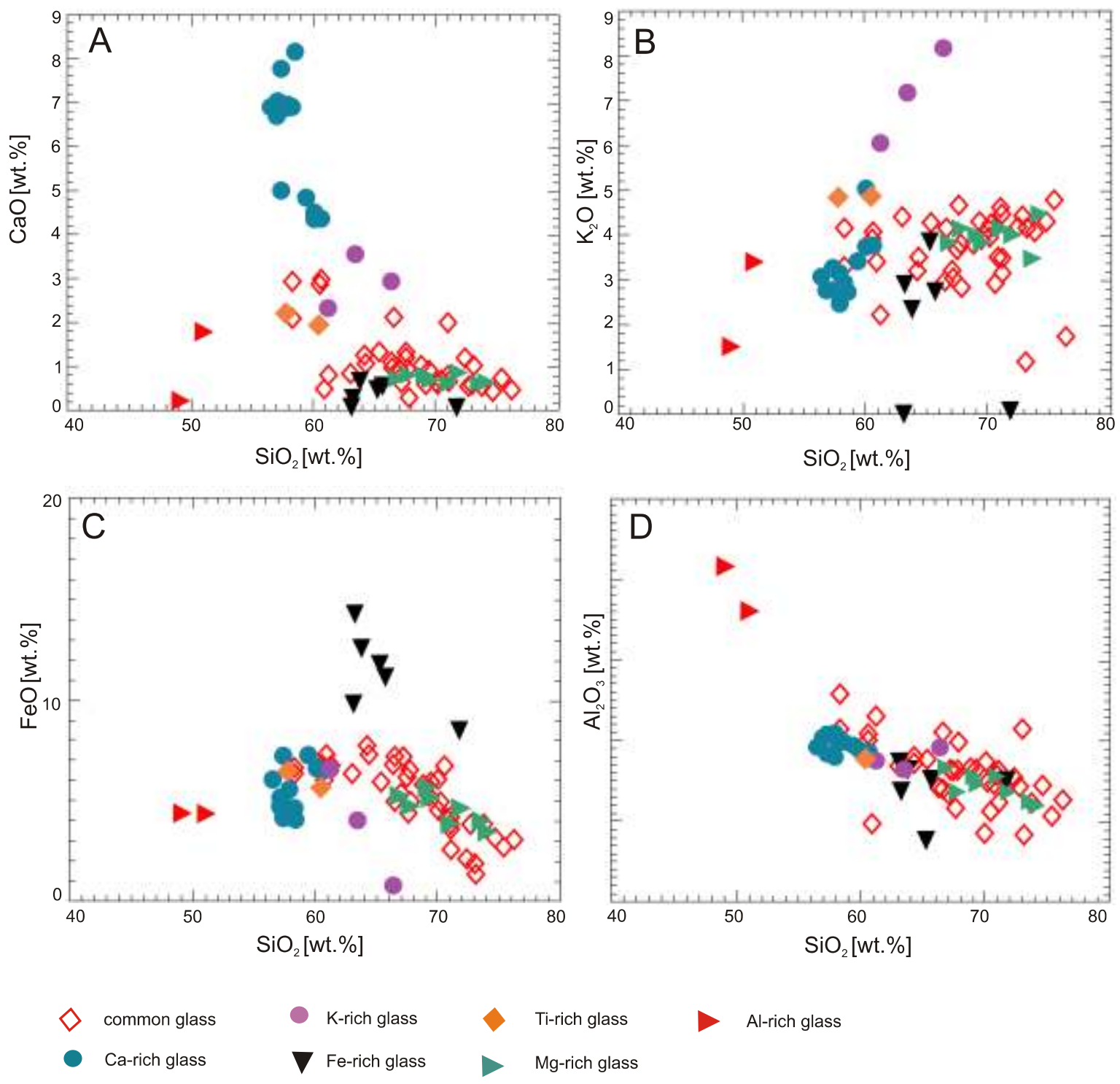

Fig. 10. $\mathrm{SiO}_{2}$ versus $\mathrm{CaO}(\mathrm{A}), \mathrm{K}_{2} \mathrm{O}(\mathrm{B}), \mathrm{FeO}(\mathrm{C})$ and $\mathrm{Al}_{2} \mathrm{O}_{3}(\mathrm{D})$ variation diagrams for glass types measured in the slags

eign cations than quartz, in particular $\mathrm{Al}$ and $\mathrm{Ca}$ (Schneider, 1986; Arahori and Suzuki, 1987). At least part of the fissures within the $\mathrm{SiO}_{2}$ phases might be interpreted as a result of fast cooling and/or replacement (e.g., Jamtveit et al., 2009) of higher temperature forms ( $\beta$-cristobalite and $\beta$-quartz) by low temperature forms ( $\alpha$-quartz and $\alpha$-cristobalite, respectively). As Grapes (2011) also showed, "with quenching ... perlitic cracking develops around the relic quartz grains due to the inversion from high to low quartz at $573^{\circ} \mathrm{C}$ '. However, no high quartz or tridymite were found by XRPD in our samples.

A mineral which might indicate the temperature is cristobalite. The formation of the high $T$ cristobalite can take place metastably already around $1000^{\circ} \mathrm{C}$ (Shoval et al., 1997; Lakshtanov et al., 2007) or $1100^{\circ} \mathrm{C}$ (Stevens et al., 1997). The low $T$ cristobalite forms upon cooling, at the $\beta$ to $\alpha$ inversion approximately between 120 and $272^{\circ} \mathrm{C}$ (Heaney, 1994), or between 210 and $230^{\circ} \mathrm{C}$ (Stevens et al., 1997). We assume that in our samples, $\beta$-cristobalite formed during heating and inverted into $\alpha$-cristobalite upon cooling.
Another interesting point regarding the temperature is the presence of plagioclase in a state of partial melting, shown by its rounded to elliptic shape (Fig. 6A) and/or reaction rims (Fig. 8). In the presence of quartz, these melting features can be interpreted based on 1 atm experiments in the system quartz-albite-anorthite-(orthoclase)- $\left(\mathrm{H}_{2} \mathrm{O}\right)$. Such experiments in the water free system were already undertaken in early times of experimental petrology (Schairer and Bowen, 1935) but did not reach equilibrium even in long term runs (5 years). Subsequently, successful experimental studies were set up only at higher pressure and various water activities (see e.g., Johannes, 1989; Johannes et al., 1994; Holtz et al., 2001). Tsuchiyama and Takahashi (1983) studied the kinetics of melting on a single plagioclase crystal with labradorite composition, at 1 bar. The first partial melt occurred after 4 minutes of heating at the solidus temperature of $1325^{\circ} \mathrm{C}$. Very fine and intimate intergrowth of feldspar and glass were described by Tsuchiyama and Takahashi (1983) as "fingerprint texture". Similar features 
have been achieved by experimentally melting plagioclase surrounded by quartz (Johannes, 1989).

1-atm-experiments in more complex systems were carried out by Brugger et al. (2003). They added small amounts of Fe and $\mathrm{Mg}$ to Qtz- $\mathrm{Ab}-\mathrm{Or}-\mathrm{An}-\mathrm{H}_{2} \mathrm{O}$ system, in order to increase the reaction rates and reduce the viscosity. The authors conducted crystallising as well as melting experiments which lead to similar results suggesting that equilibrium conditions were attained. The compositions found in the common glass of the Lăpuş slags are similar in respect to $\mathrm{SiO}_{2}, \mathrm{Al}_{2} \mathrm{O}_{3}, \mathrm{TiO}_{2}, \mathrm{MgO}$ and $\mathrm{CaO}$ to those of the synthetic and natural substances used by Brugger et al. (2003). They found solid phases (quartz and/or plagioclase) only up to $1200^{\circ} \mathrm{C}$, no crystals in the melts at $1250^{\circ} \mathrm{C}$ were observed. Crystallising and melting experiments showed the formation of plagioclase compositions with $\mathrm{An}_{36-65}$ between 990 and $1190^{\circ} \mathrm{C}$. This fits quite well to the plagioclase composition measured in our slags (Table 4). Their synthetic phase diagram (Brugger et al., 2003, fig. 7) displays the stability of several phases, depending on temperature and composition in terms of $\mathrm{SiO}_{2}$. Upon melting, plagioclase would disappear at $\sim 1200^{\circ} \mathrm{C}$ independent of the overall composition. At high silica amount (>75 wt.\%), quartz would also disappear at the same temperature. At lower $\mathrm{SiO}_{2}(\sim 67 \mathrm{wt} . \%)$, quartz already disappears at $1100^{\circ} \mathrm{C}$. At the same compositions, orthopyroxene would also melt at $1100^{\circ} \mathrm{C}$.

Another feature of the Lăpuş slags is the lack of any relics of muscovite and biotite and/or clay minerals such as illite, kaolinite or montmorillonite, respectively. According to Grapes (2006), based on Cole and Segnit (1963), Fe-rich clay minerals or mica should decompose above $1100^{\circ} \mathrm{C}$ to form $\mathrm{FeO}$ and glass. Muscovite and illite start to decompose at temperatures ranging from 700 to $900^{\circ} \mathrm{C}$ (e.g., Maggetti, 1982; Murad and Wagner, 1996; Riccardi et al., 1999; Cultrone et al., 2001 and references therein).

As shown in Figure 6B, rutile - a relic from the original sherd, starts to melt forming a "Ti-rich glass" (Table 4). Rutile is stable up to $1200^{\circ} \mathrm{C}$ (Maggetti, 1982) thus its incipient dissolving points to this temperature. Brugger et al. (2003) found that formation of the FeTi-oxides takes place around $1110-1160^{\circ} \mathrm{C}$, spinel starts to form around $1050^{\circ} \mathrm{C}$ (Maggetti, 1994) whereas mullite appears at $T>950^{\circ}$ (Maggetti and Rossmanith, 1981; Maggetti, 1982). In the presence of cristobalite and "silicic acid" mullite nucleates at 1200 and $1300^{\circ} \mathrm{C}$, as demonstrated by Wahl et al. (1961). The newly formed Fe-rich phases can be described within the system $\mathrm{FeO}\left(+\mathrm{Fe}_{2} \mathrm{O}_{3}\right)-\mathrm{Al}_{2} \mathrm{O}_{3}-\mathrm{SiO}_{2}$. Fayalite would appear in this system on the liquidus between 1200 and $1100^{\circ} \mathrm{C}$ (Schairer and Yagi, 1952). Ferrosilite is also a part of the system but it is difficult to interpret. At $1 \mathrm{~atm}$ pressure it is metastable with respect to fayalite $+\mathrm{SiO}_{2}$ (Smith, 1971).

Taking into account all the above discussed mineral features, a range of temperature between $\sim 1100$ and $\sim 1200^{\circ} \mathrm{C}$ can be envisaged for the formation of the Lăpuş slags. The cooling of the melt was fast as documented not only by the formation of the highly vesicular mass of strongly inhomogenous composition but also by the lack of recrystallisation, i.e. the formation of a glass.

\section{CONSIDERATIONS REGARDING}

THE NOMENCLATURE

The Lăpuş slag pieces have originated from melting older ceramic pots. Initially, these consisted of a mixture of siltic mudstone with various temper materials. The ceramics, in particular that with a high fraction of glass and a high vesicularity, is similar to "buchites" (see Grapes, 2006, 2011). This term, among others such as clinker or paralava, is used for natural slags, which formed as "...an extensively vitrified rock resulting from intense contact metamorphism...” (Grapes, 2011), “...vitrified hornfels produced by fusion of an argillaceous rock by intense local thermal metamorphism..." (Neuendorf et al., 2005), or a "melted pelite" (Grapes, 2006).

Ceramics can be regarded as an artificial rock (Maggetti, 2001) produced by "anthropogenic pyrometamorphism" (Grapes, 2006, 2011). To avoid confusion with these natural slags i.e. "buchites", we propose to utilize the term "ceramic slags" for the vitreous and porous material resulting by overfiring/melting/fast cooling of former ceramic ware.

\section{CONCLUSIONS}

In the Bronze Age funerary site of Lăpuş, occasional uncontrolled burning most likely set within a ritual context led to the formation of artifacts with peculiar features. The temperature of the fire was high enough to deform and eventually to melt former ceramic vessels, which may have been filled with offerings. Thus, the ceramic material already fired once when producing the pot, underwent a second thermal event, i.e. was refired. As the temperature arose, almost all mineral components including the clayey matrix and micas, except for quartz, plagioclase and FeTi oxides were completely melted. The resulting molten mass boiled and produced gas bubbles. The transformation of quartz into high $T$ polymorphs ( $\beta$-cristobalite), the partial melting of plagioclase and the incipient melting of rutile, all mark the peak of the thermal event around $1200^{\circ} \mathrm{C}$. The crystallisation of new phases (fayalite, ferrosilite, magnetite-dominated spinel, hematite, mullite, clinopyroxene and cordierite), was followed by cooling during which the inversion of part of the $\mathrm{SiO}_{2}$ polymorphs to lower $T$ modification ( $\alpha$-quartz, $\alpha$-cristobalite) and formation of a glassy mass with a vesicular appearance took place. The resulting material is the "ceramic slag".

The glass shows inhomogeneous appearance and composition as result of: a) melting/partial melting of primary mineral phases and b) incomplete mixing of the melt due to lack of time and fast cooling. Several chemical groups were identified, based on the enrichment of one oxide: "common glass", "Al-rich glass", "Fe-rich glass", "Ca-rich glass", "K-rich glass", "Mg-rich glass" and a "Ti-rich glass", respectively. These slags are not related to any metallurgical processes, but are results of "anthropogenic pyrometamorphism” (sensu Grapes, 2006, 2011), i.e. melting of former ceramic vessels during funerary rituals. 
Acknowledgments. Many thanks are due to Dr. R. Kryza (Wroclaw University, Poland), Dr. M. Maggetti (University of Fribourg, Switzerland) and Dr. U. Schüßler (Würzburg University, Germany) for careful revision and checking the manuscript. Their comments and suggestions greatly helped the improving of the text. Thanks are due to Mrs. M. Mereu and Dr. F. Forray (Babeş-Bolyai University Cluj-Napoca) for computer-assisted drawings and photos of slag pieces, respectively. M.Sc. G. Tippelt (University of Salzburg) is thanked for XRPD. The barrow no. 26 under study was excavated in a joint project of the Institut für Vor- und Frühgeschichtliche Archäologie und
Provinzialrömische Archäologie of the Ludwig-MaximiliansUniversität Munich (Germany), the County Museum of Maramureş for History and Archaeology in Baia Mare (Romania), and several other scientific partners. The study was financed by Deutsche Forschunsgemeinschaft Program (DFG) 2008-2011 Project granted to C.M.-N. The research was also supported by the Romanian Ministry of Education and Research, through ID-2241/2008 (CNCSIS/UEFISCDI/) Project (part of the analyses) and PN-II-ID-PCE-2011-3-0881 (CNCS/UEFISCDI) Project (part of the analyses and the editing of the manuscript).

\section{REFERENCES}

ALDEN J.R. (1988) - An Uruk period pottery production tool. Paléorient, 14 (1): $143-150$.

ANDERSON T.J., AGUSTONI C., DUVAUCHELLE A., SERNEELS V. and CASTELLA D. (2003) - Des artisans a la Campagne. Carrière de meules, forge et voie gallo-romaines à Châbles (FR). Acad. Press Fribourg.

ARAHORI T. and SUZUKI T. (1987) - Transformation of tridymite to cristobalite below $1470^{\circ} \mathrm{C}$ in silica refractories. J. Mater. Sc., 22: 2248-2252.

BLAKELOCK E., MARTINÓN-TORRES M., VELDHUIJZEN H.A. and YOUNG T. (2009) - Slag inclusions in iron objects and the quest for provenance: an experiment and a case study. J. Archaeol. Sc., 36: $1745-1757$.

BRUGGER C.R., JOHNSTON A.D. and CASHMAN K.V. (2003) - Phase relations in silicic systems at one-atmosphere pressure. Contr. Miner. Petrol., 146: 356-369.

BUCHWALD V.F. and WIVEL H. (1998) - Slag analysis as a method for the characterization and provenancing of ancient iron objects. Mater. Charact., 40: 73-96.

CANTI M.G. (2003) - Aspects of the chemical and microscopic characteristics of plant ashes found in archaeological soils. Catena, 54: 339-361.

COLE W.F. and SEGNIT E.R. (1963) - High-temperature phase developed in some kaolinite-mica-quartz clays. Trans. Brit. Ceram. Soc., 62 375-395.

CULTRONE G., RODRIGUEZ-NAVARRO C., SEBASTIAN E., CAZALLA O. and de la TORRE M.J. (2001) - Carbonate and silicate phase reactions during ceramic firing. Eur. J. Miner., 13: 621-634.

DEGRYSE P., MUCHEZ P.H., SIX S. and WAELKENS M. (2003) - Identification of ore extraction and metal working in ancient times: a case study of Sagalassos (SW Turkey). J. Geochem. Explor., 77: 65-80.

FREESTONE I.C., MEEKS N.D. and MIDDLETON A.P. (1985) - Retention of phosphate in buried ceramics: an electron microbeam approach. Archaeometry, 27 (2): 161-177.

FREESTONE I.C., MIDDLETON A.P. and MEEKS N.D. (1994) - Significance of phosphate in ceramic bodies: discussion of paper by Bollong et al. J. Archaeol. Sc., 21: 425-426.

GIUŞCĂ D., RĂDULESCU D., GHERASI N., BOMBI $\breve{A}$ G., VASILESCU A. and KRÄUTNER H. (1967) - Geological map of Romania 1:200 000, Baia Mare sheet. Geol. Inst., Bucharest.

GOLDEN J.M. (2009) - Ancient Canaan and Israel: an introduction. Oxford University Press.

GRAPES R. (2006) - Pyrometamorphism. Springer, Berlin-Heidelberg-New York.

GRAPES R. (2011) - Pyrometamorphism. Springer, Berlin-Heidelberg.

GRAPES R., ZHANG K. and PENG Z-L. (2009) - Paralava and clinker products of coal combustion, Yellow River, Shanxi Province, China. Lithos, 113: 831-843.
GRAPES R., KORZHOVA S., SOKOL E. and SERYOTKIN Y. (2011) Paragenesis of unusual Fe-cordierite (sekaninaite)-bearing paralava and clinker from the Kuznetsk coal basin, Siberia, Russia. Contr. Miner. Petrol., 162: 253-273.

HEANEY P.J. (1994) - Structure and chemistry of the low-pressure silica polymorphs. Rev. Miner., 29: 1-40.

HEIMANN R.B., CHIRIKURE S. and KILLICK D. (2010) - Mineralogical study of precolonial (1650-1850 CE) tin smelting slags from Rooiberg, Limpopo Province, South Africa. Eur. J. Miner., 22: 751-761.

HEIN A., KILIKOGLOU V. and KASSIANIDOU V. (2007) - Chemical and mineralogical examination of metallurgical ceramics from a late Bronze Age copper smelting site in Cyprus. J. Archaeol. Sc., 34: 141-154.

HOECK V., IONESCU C., GHERGARI L. and PRECUP C. (2009) - Towards mineralogical and geochemical reference groups for some Bronze Age ceramics from Transylvania (Romania). Studia Univ. Babeș-Bolyai, 54 (2): 41-51.

HOLTZ F., BECKER A., FREISE M. and JOHANNES W. (2001) - The water-undersaturated and dry Qz-Ab-Or system revisited. Experimental results at very low water activities and geological implications. Contr. Miner. Petrol., 141: 347-357.

IANOVICI V., RĂDULESCU D., PATRULIUS D., BOMBI Ă GH., KRÄUTNER H. and KRÄUTNER F. (1968) - Geological map of Romania, 1:200 000, Vişeu sheet. Geol. Inst., Bucharest.

IONESCU C. and HOECK V. (2011) - Firing-induced transformations in Copper Age ceramics from NE Romania. Eur. J. Miner., 23 (6): 937-958.

IONESCU C., HOECK V. and GHERGARI L. (2011) - Electron microprobe analysis of ancient ceramics: a case study from Romania. Appl. Clay Sc., 53 (3): 466-475.

ISSI A., KARA A. and ALP A.O. (2011) - An investigation of Hellenistic Period pottery production technology from Harabebezikan/Turkey. Ceram. Int., 37: 2575-2582.

JAMTVEIT B., PUTNIS C.V. and MALTHE-SøRENSSEN A. (2009) Reaction induced fracturing during replacement processes. Contr. Miner. Petrol., 157: 127-133.

JOHANNES W. (1989) - Melting of plagioclase-quartz assemblages at 2 kbar water pressure. Contr. Miner. Petrol., 103: 270-276.

JOHANNES W., KOEPKE J. and BEHRENS H. (1994) - Partial melting reactions of plagioclase-bearing systems. In: Feldspars and their reactions (ed. I. Parson): 161-194. Kluwer Acad. Publ.

JURJE M. (2012) - Quartz andesites from the Oaş-Gutâi Neogene volcanic area (Romania). PhD thesis, Babeş-Bolyai University Cluj-Napoca.

KACSÓ C. (1975) - Contributions à la connaissance de la culture de Suciu des Sus à la lumière des recherché faites à Lăpuş. Dacia N. S., 19: $45-68$. 
KACSÓ C. (2001) - Zur chronologischen und kulturellen Stellung des Hügelgräberfeldes von Lăpuş. In: Der Nordkarpatische Raum in der Bronzezeit (ed. C. Kacsó): 231-278. Symp. Baia Mare, 7-10 October, 1998. Bibl. Marmatia I.

KACSÓ C., METZNER-NEBELSICK C. and NEBELSICK L.D. (2012) Kontinuität und Diskontinuität im Bestattungsverhalten der spätbronzezeitlichen Eliten in Nordwestsiebenbürgen am Beispiel der Hügelnekropole von Lăpuş in Nordwestrumänien. Bodenaltertümer Westfalens, 51: 457-475.

KIERCZAK J. and PIETRANIK A. (2011) - Mineralogy and composition of historical Cu slags from the Rudawy Janowickie Mountains, Southwestern Poland. Can. Miner., 49: 1281-1296.

LAKSHTANOV D.L., SINOGEIKIN S.V. and BASS J.D. (2007) High-temperature phase transition and elasticity of silica polymorphs. Phys. Chem. Miner., 34: 11-22.

MAGEE M.J., WAYMAN M.L. and LOVELL N.C. (1996) - Chemical and archaeological evidence for the destruction of a sacred animal necropolis at ancient Mendes, Egypt. J. Archaeol. Sc., 23: 485-492.

MAGGETTI M. (1982) - Phase analysis and its significance for technology and origin. In: Archaeological Ceramics (eds. J.S. Olin and A.D. Franklin): 121-133. Smithsonian Inst. Press.

MAGGETTI M. (1994) - Mineralogical and petrographical methods for the study of ancient pottery. In: 1st European Workshop on Archaeological Ceramics, 10-12 October, 1991 (eds. F. Burragato, O. Grubessi and L. Lazzarini): 23-35. Università degli studi La Sapienza, Roma.

MAGGETTI M. (2001) - Chemical analyses of ancient ceramics: what for? Chimia, 55: 923-930.

MAGGETTI M. and ROSSMANITH M. (1981) - Archaeothermometry of kaolinitic clays. Rev. Archéom., Suppl.: 185-94.

MARITAN L. and MAZZOLI C. (2004) - Phosphates in archaeological finds: implications for environmental conditions of burial. Archaeometry, 46: 673-683.

MARITAN L., MAZZOLI C., NODARI L. and RUSSO U. (2005) - Second Iron Age grey pottery from Este (northeastern Italy): study of provenance and technology. Appl. Clay Sc., 29: 31-44.

MARITAN L., ANGELINI I., ARTIOLI G., MAZZOLI C. and SARACINO M. (2009) - Secondary phosphates in the ceramic materials from Frattesina (Rovigo, North-Eastern Italy). J. Cult. Herit., 10: $144-151$

McGOWAN G. and PRANGNELL J. (2006) - The significance of vivianite in archaeological settings. Geoarchaeol., 21 (1): 93-111.

METZNER-NEBELSICK C., KACSÓ C. and NEBELSICK L.D. (2010) A Bronze Age ritual structure on the edge of the Carpathian Basin. Stud. Comun. Satu Mare, 26 (1): 219-233.

MURAD E. and WAGNER U. (1996) - The thermal behaviour of an Fe-rich illite. Clay Miner., 31: 45-52.

NEUFFER L. (1997) - Schlacken ausserhalb der Eisenmetallurgie/Scories sans rapport avec la métalurgie du fer. In: Technique des fouilles grabungstechnik. Minerai, scories, fer. Erze, Schlakenbk, Eien. GSAF/SAGEA Fribourg: 58-64.

NEUENDORF K.K.E., MEHL J.P. and JACKSON J.A., eds. (2005) Glossary of geology. AGI, Alexandria VA.

PETRIE C.A. (2012) - Ceramic production. In: A Companion to the Archaeology of the Ancient Near East (ed. D.T. Potts): 279-294. Blackwell Publ. Ltd.

REHREN T., CHARLTON M., CHIRIKURE S., HUMPHRIS J., IGE A. and VELDHUIJZEN H.A. (2007) - Decisions set in slag: the human factor in African iron smelting. In: Metals and Mines: Studies in Archaeometallurgy (eds. S.L. Niece, D. Hook and P. Craddock): 211-218. Archetype, London.

REHREN T., BOSCHER L. and PERNICKA E. (2012) - Large scale smelting of speiss and arsenical copper at Early Bronze Age Arisman, Iran. J. Archaeol. Sc., 39 (6): 1717-1727.

RICCARDI M.P., MESSIGA B. and DUMINUCO P. (1999) - An approach to the dynamics of clay firing. Appl. Clay Sc., 15: 393-409.

SAFFARZADEH A., SHIMAOKA T., MOTOMURA Y. and WATANABE K. (2006) - Chemical and mineralogical evaluation of slag products derived from the pyrolysis/melting treatment of MSW. Waste Managem., 26: 1443-1452.

SĂNDULESCU M. (1984) - Geotectonics of Romania (in Romanian). Edit. Tehn. Bucharest.

SĂNDULESCU M., KRÄUTNER H., BORCOȘ M., NĂSTĂSEANU S., PATRULIUS D., ŞTEFĂNESCU M., GHENEA C., LUPU M., SAVU H., BERCIA I. and MARINESCU F. (1978) - Geological map of Romania, 1:1 000 000. Geol. Geophys. Inst., Bucharest.

SCHAIRER J.F. and BOWEN N.L. (1935) - Preliminary report on equilibrium-relations between feldspathoids, alkali feldspars and silica. Am. Geophys. Union Trans., 16th Ann. Meet.: 325-328.

SCHAIRER J.F. and YAGI K. (1952) - The system $\mathrm{FeO}-\mathrm{Al}_{2} \mathrm{O}_{3}-\mathrm{SiO}_{2}$. Am. J. Sc., 250A: 471-512.

SCHNEIDER H. (1986) - Chemical composition of tridymite and cristobalite from volcanic and meteoritic rocks. N. Jb. Min. Mh., (10): 433-444.

SERNEELS V. (1995) - Du minérai à l'object: un village de sidérurgistes du IXe au XIIe siècle à Liestal-Röserntal BL. Ländliche Siedlungen zwischen Spätantike und Mittelalter. Archäol. Mus., 33: 35-43.

SERNEELS V. and CREW P. (1997) - Ore-slag relationship from experimentally smelted bog-iron ore. Plas Tan y Bwlch Occ. Papers, 3: 78-82.

SHARP W.E. and MITTWEDE S.K. (2011) - Late-medieval plagioclase-titanaugite-bearing iron slags of the Yaprakli Area (Çankiri), Turkey. Turk. J. Earth Sc., 20: 321-335.

SHOVAL S. (1993) - The burning temperature of a Persian-Period pottery kiln at Tel Michal, Israel, estimated from the composition of slag-like material formed in its wall. J. Therm. An., 39: 1157-1168.

SHOVAL S., CHAMPAGNON B. and PANCZER G. (1997) - The quartz-cristobalite transformation in heated chert rock composed of micro and crypto-quartz by micro-Raman and FT-IR spectroscopy methods. J. Therm. An., 50: 203-213.

SIGURDSSON H., HOUGHTON B.F., McNUTT S.R., RYMER H. and STIX J., eds. (2000) - Encyclopedia of volcanoes. Acad. Press, San Diego-San Francisco-New York.

SIIVOLA J. and SCHMID R. (2007) - List of mineral abbreviations. Recommendations by the IUGS Subcommission on the Systematics of Metamorphic Rocks: www.bgs.ac.uk/scmr/home.html

SMITH D. (1971) - Stability of the assemblage iron-rich orthopyroxeneolivine-quartz. Am. J. Sc., 271: 370-382.

STEVENS S.J., HAND R.J. and SHARP J.H. (1997) - Temperature dependence of the cristobalite $\alpha-\beta$ inversion. J. Therm. An., 49: 1409-1415.

STONE E.C. and ZIMANSKY P.E. (2004) - The anatomy of a Mesopotamian city: survey and soundings at Mashkan-shapir. Eisenbrauns Winona Lake, In.

THY P., SEGOBYE A.K. and MING D.W. (1995) - Implication of prehistoric glassy biomass slag from East-Central Botswana. J. Archaeol. Sc., 22: 629-637.

TITE M.S. and MANIATIS Y. (1975) - Examination of ancient pottery using the scanning electron microscope. Nature, 257: 122-123.

TRABER D., MÄDER U.K. and EGGENBERGER U. (2002) - Petrology and geochemistry of a municipal solid waste incinerator residue treated at high temperature. Schweiz. Miner. Petrogr. Mitt., 82: 1-14.

TSUCHIYAMA A. and TAKAHASHI E. (1983) - Melting kinetics of a plagioclase feldspar. Contr. Miner. Petrol., 84: 345-354.

VELDHUIJZEN H.A. (2005) - Technical ceramics in early iron smelting: the role of ceramics in the early first millennium $\mathrm{BC}$ iron production at Tell Hammeh (Az-Zarqa), Jordan. In: Understanding People Through their Pottery (eds. I. Prudęncio, I. Diasand and J.C. Waerenborgh): 295-302. Proceedings of the 7th European Meeting on Ancient Ceramics (EMAC 2003), Lisboa.

WAHL F.M., GRIM R.E. and GRAF R.B. (1961) - Phase transformations in silica-alumina mixtures as examined by continuous X-ray diffraction. Am. Miner., 46: 1064-1076.

ZACHARIAS N., MICHAEL C., PHILANIOTOU-HADJIANASTASIOU O., HEIN A. and BASSIAKOS Y. (2006) - Fine-grain TL dating of archaeometallurgical furnace walls. J. Cult. Herit., 7: 23-29. 